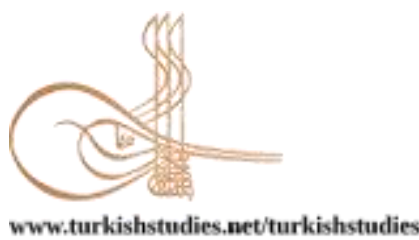

Turkish Studies

\title{
Bir Mizah Virüsü Olarak Kovid-19: Ağ Toplumunda Siber Mizah Yaratmak
}

\author{
As a Humor Virus Covid-19: Creatıng Cyber Humor In The Network Soclety
}

\author{
Cevdet Avc1*
}

\begin{abstract}
Oral, written and electronic cultural environments determine the production and consumption styles of culture. When using dynamic recording and transfer systems based on memory in an oral culture environment, cultural texts become static structures in a written environment. The electronic cultural environment expands the communication network of culture, adding auditory and visual dimensions to this network. In addition, in this environment, the concept of time and space changes. The proliferation of computers, smartphones and other mobile devices has led to a new interaction environment in the build-up with internet usage. Members of this environment form the network community. In a new cultural environment through social networks, a virtual culture has been formed with the increasing use of social media such as Facebook, Twitter, Instagram and YouTube. These social media channels, which allow members of the network community to interact quickly, enable the conversion of traditional cultural elements and consumption. On the other hand, instant interaction can be interacted in the form of communication on social media in a similar way to the oral cultural environment. The subject of the article is humor, which is one of these forms of sharing. Humor on social media is often produced based on current events. In this context, the kovid-19 epidemic, which affects the world and negatively affects human life economically, socially and psychologically, has become the current topic of social media humor. The purpose of the article is to examine the way the network community interacts and creates humor within the framework of the covid-19 virus. In this context, literature was scanned first and the data was collected and examined by document analysis technique. Social media channels, Facebook, Twitter, Instagram and YouTube have scanned accounts through the stream, detecting humor content about the viral covid-19 virus. The examination showed that people who communicate via social media networks interacted in a similar way to the verbal culture. This etiks is that it can include personal and social issues in everyday life. The covid-19 virus has been one of the tools of the network community to generate humor through social media. It has been observed that humor content produced and shared in this regard are in everyday life, work, cleaning, quarantine, food and goods stock, education and training. Humorous elements on covid-19 were found to consist mostly of written and visual content.
\end{abstract}

Structured Abstract: The article focused on the communication and interaction of the network community through examples of cyber humor related to the covid-19 virus. The formation of the network community began with technology creating virtual cultural environments that connect individuals and societies. The computer's

\footnotetext{
* Dr. Öğr. Üyesi, Gaziantep Üniversitesi, Fen Edebiyat Fakültesi, Türk Dili ve Edebiyatı Bölümü Asst. Prof. Dr., Gaziantep University, Faculty of Arts and Sciences, Department of Turkish Language and Literature

ORCID 0000-0003-0948-1659

cevdetavci@hotmail.com

Cite as/ Atıf: Avcı, C. (2020). Bir mizah virüsü olarak Kovid-19: Ağ toplumunda siber mizah yaratmak. Turkish Studies, 15(3), 1657-1684. https://dx.doi.org/10.29228/TurkishStudies.42868

Received/Geliş: 12 April/Nisan 2020

Accepted/Kabul: 20 June/Haziran 2020

Copyright $\odot$ MDE, Turkey
} 
adventure, which began with military and commercial activities, has revealed significant cultural consequences with portable mobile devices and the Internet. The Internet is an important tool for globalizing culture in the form of an international network by connecting individuals and societies. The development of communication technologies and the proliferation of portable mobile devices have revealed a new form of social interaction over virtual networks on the internet. This way of interaction also expands its socio-cultural, political and economic sphere by incorporatering the person into new cultural circles. Interaction over virtual networks; local, national and internationally interactive networking society. The internet environment, which provides a wide range of possibilities on a variety of topics such as entertainment, criticism and intelligence, also gives the person a sense of freedom. The ability to be available on social networks using real identities or fake IDs increases the usage rates of these networks. The person who exists in social life with real identity is also in a public space. In this field, certain duties, responsibilities and limitations are assumed. However, the way the internet environment exists with multiple identities does not include these elements. This new form of membership of the network community creates flexible and often accountable Identities.

Members of the network community interact and share up-to-date in physical reality and in a similar lyinous cultural environment. The person who set up his own media in the new media environment can react to his individual attitude about current events as an instant reaction. In the study, examples of written, auditory, visual and audiovisual cyber humor were collected on Facebook, Twitter, Instagram and YouTube browsing during the corona virus outbreak process. The fact that the corona virus was first the topic of the agenda in foreign countries and then in Turkey was met with a humorous attitude on social networks. The network community's reaction to the virus epidemic, which affects everyday life on all sides, has been in the form of creating cyber humor. The current indexed cultural production-consumption style of the virtual environment has emerged with its humor dimension.

In the study, visual humor elements were found to be at the forefront of humor content produced with the corona virus agenda. Cartoons, photographs and caps are used in visual content. Although the element of laughter is evident in these content, critical attitude has also been seen. Rather than the production of a humor content; the sharing format, the frequency of sharing, the fact that it is circulating on multiple social networks indicates that social network members have adopted the thought and mood that the content reflects. The topics of the humor content produced also show the way in which the virus affects society. The written, visual, audiovisual materials used as an example in the study are given as well as within the specific subject ranking. It is seen that the issues of corona virus, cleaning-cologne, education and training processes, quarantine, food and goods stockists come to the fore. These issues show in what ways the virus is reflected in everyday life. Humor, on the other hand, is the twisting of the truth and expressing it in another language. Instead of escaping the virus, the virus-related posts send a message of fighting it. With the arrival of the corona virus in Turkey, legal measures were taken. Warnings about drawing attention to social distance and hygiene rules to protect against the virus have been the subject of humor. Schools have been closed and moved to distance education in case the virus outbreak spreads. Universities have been involved in this practice. This has brought to the agenda the education and training processes, given the age range of social media users. Spending time with the family at home, curfew, distance education practices have been included in written and visual humor content. Another agenda topic in partial quarantine processes has been stockpiling food and cleaning supplies. The use of pasta, cologne and other cleaning products is reflected in the humor content produced.

As a result, it can be said that the network community is instantly communicated and interacting in a similar way to the oral culture environment. The epidemic process is reflected in this interaction with the size of humor. The contagion of laughing; In the new environments of culture, it becomes the contagion of the humor that created it. In the case of corona virus, the transport network caused the virus to spread around the world, while the communication network corona spread the humor virus. The society connected with fiber networks interacted by producing and sharing cyber humor on these networks.

Keywords: Network society, social media, communication, siber humor, corona virüs.

Öz: Sözlü, yazılı ve elektronik kültür ortamları, kültürün üretim-tüketim tarzlarını belirler. Sözlü kültür ortamında belleğe dayalı dinamik kayıt ve aktarım sistemleri kullanılırken yazılı ortamda kültürel metinler statik yapıara dönüşür. Elektronik kültür ortamı, kültürün iletişim ağını genişleterek bu ağa işitsel ve görsel boyutlar katar. Ayrıca bu ortamda, zaman ve mekân kavramını değişir. Bilgisayar, akıllı telefon ve diğer mobil 
cihazların yaygınlaşması, internet kullanımıyla birikte yeni bir etkileşim ortamının doğmasını sağlamıştır. Bu ortamın üyeleri ağ toplumunu oluşturur. Sosyal ağlar üzerinden oluşan yeni kültür ortamında Facebook, Twitter, Instagram ve YouTube gibi sosyal medya mecralarının kullanımının artması ile birlikte sanal bir kültür oluşmuştur. Ağ toplumunun üyelerinin hızlı etkileşimine imkân tanıyan bu sosyal medya kanalları, geleneksel kültür unsurlarının dönüştürülerek tüketimini sağlar. Diğer taraftan, sosyal medyadaki iletişim biçiminde sözlü kültür ortamına benzer şekilde anlık etkileşime girilebilmektedir. Makalenin konusunu bu paylaşım biçimlerinden birisi olan mizah teşkil etmektedir. Sosyal medyada mizah, çoğunlukla güncel olaylar konu alınarak üretilmektedir. Bu bağlamda dünyayı etkisi altına alarak insan sağlığıyla birlikte toplum hayatını ekonomik, sosyal ve psikolojik yönden olumsuz etkileyen kovid-19 salgını, sosyal medya mizahının güncel konusu olmuştur. Makalenin amacı ağ toplumunun etkileşim ve mizah yaratma biçimini kovid-19 virüsü çerçevesinde incelemektir. Bu kapsamda öncelikle literatür taraması yapılmış, veriler doküman analizi tekniğiyle toplanmış ve incelenmiştir. Sosyal medya kanalları olan Facebook, Twitter, Instagram ve YouTube'daki akış üzerinden hesaplar taranarak dolaşımdaki kovid-19 virüsü konulu mizah içerikleri tespit edilmiştir. Yapılan incelemede sosyal medya ağları üzerinden iletişime geçen insanların sözlü kültürdekine benzer biçimde tepkisel ve anlık etkileşime girdikleri görülmüştür. Bu etikileşim, gündelik hayat içerisinde kişisel ve toplumsal konuları içerebilmektedir. Kovid-19 virüsü, ağ toplumunun sosyal medya üzerinden mizah üretme araçlarından birisi olmuştur. Bu konuda üretilip paylaşılan mizah içeriklerinin gündelik hayat, iş, temizlik, karantina, yiyecek ve eşya stoğu, eğitim-öğretim gibi konularda olduğu görülmüştür. Kovid-19 konulu mizahi unsurların çoğunlukla yazılı ve görsel içeriklerden oluştuğu tespit edilmiştir.

Anahtar Kelimeler: A ̆g toplumu, sosyal medya, iletişim, siber mizah, korona virüsü.

\section{Giriş}

Bireysel ve toplumsal iletişim olgusu sözlü, yazılı ve elektronik kültür ortamlarında farklı boyutlar kazanır. Yazılı kültürün iletişim biçiminde, sözel iletişimin içeriğini oluşturan öğeler olan "ileti, kaynak, hedef kitle ve kanal arasındaki eşzamanlılık" ile "söz, giyim, dekor, mekân" gibi iletişimin diğer bileşenleri bulunmaz (Oskay, 2011: 10, 24). Bilimsel bilginin insan hayatına teknoloji olarak yansıması, kültür tarihinin önemli noktalarından birisidir. İletişim teknolojilerinin gelişmesiyle kültürün kayıt, paylaşım ve aktarım biçimleri değişmiştir. Ortaya çıkan elektronik kültür, sözlü kültür tarzı anlık bir etkileşim-iletişim ortamı yaratmıştır. Bu yeni kültürel ortamda işitsellik ve görsellik ön plandadır. Sözlü, yazılı ve elektronik kültür ortamları aynı zamanda farklı düşünme tarzlarını oluşturur. Sözel zihnin düşünme biçiminde "serbestlik ve dinamik" belirginken yazılı zihin "kalıplarla" düşünür (Ong, 2013: 62). Elektronik kültürle birlikte insanın düşünce dünyasında "sanal/dijital kültür bağlamları ve geçişleri" ortaya çıkmıştır. Özdemir'in ifadesiyle; "Doğal olarak, önceki kültür bağlamları gibi sanal kültür de insanlığın var olan ve yaşayan kültürel birikiminden yararlanılarak yaratılmış ve alıntılanan ya da aktarılan kültürel birikim çeşitli değişikliklere uğramıştır" (Özdemir, 2009: 1277-1301). Geleneksel aktarım biçimlerinin yerini alan dijital iletişim, sanal ortamlarda kültür üreticileri ve tüketicilerini buluşturur.

$\mathrm{Bu}$ bağlamda, ortaya çıkan internet tabanlı yeni mobil iletişim teknlojileriyle zaman ve mekân kavramının değiştiği bir etkileşim ortamı doğmuştur. Sosyal medyanın bir araya getirdiği bu yeni ortamın üyeleri ağ toplumunu oluşturur. Ağ toplumu, bir taraftan belirli aidiyetler üzerinden bir araya gelirken bir taraftan da uluslararası boyuta ulaşacak kadar geniş bir yelpazede buluşabilmektedir. Burada belirleyici olan, bir araya gelinen sosyal medya kanalı ve paylaşılan bilgi türüdür. Dolayısıyla yeni paylaşım ortamı, bu geniş zemine uygun biçimde ülke ve dünya gündemine paralel konularla şekillenebilmektedir. Siber ağlar üzerinden bir araya gelen yeni toplumun etkileşim tarzı genellikle tepkiseldir. Bu tepki biçimlerinden birisi mizahtır. Mizahın sözlü ve yazılı kültür ortamlarındaki eğlence ve eleştiri işlevleri, ağ toplumu tarafından dijital kültür ortamında da kullanılır. Bu çalışmada ağ toplumunun mizah yaratma biçimi, kovid-19 virüsü çerçevesinde ele alınmıştır. İnsan sağlığı, ekonomi ve gündelik hayatın pek çok alanında olumsuz etkileri görülen kovid-19 salgını, internet ortamında öncelikle mizah tepkisiyle karşılanmıştır. Makalede ağ toplumunun ürettiği bu mizah biçimi, siber mizah olarak nitelenmiştir. Bu kapsamda öncelikle 
literatür taraması yapılmış, veriler doküman analizi tekniğiyle toplanmış ve incelenmiştir. Makalede Facebook, Twitter, Instagram gibi sosyal ağlar ile video paylaşım sitesi olan YouTube taranmış anlık mesajlaşma uygulaması olan WhatsApp^taki görsel içeriklere de yer verilmiştir. Kullanılan veriler, yaygın olarak dolaşımda olan mizah içeriklerinden örneklem olarak seçilmiştir. İçeriklerin birden fazla sosyal medya kanalında ifade, yorum ve emoji eklenerek paylışılması, görsel içeriklerin üretildiği kaynăğ bulmayı zorlaştırmıştır. Bu durum, makalede kullanılan görsel içeriklere künye eklenmesinde ortaya çıkan sınırlılıklardan birisidir. Görsel içeriklerin bir kısmı kişisel WhatsApp gruplarında yapılan paylaşımlardan alınmış ve bunlar makalede belirtlilmiştir. Kullanılan yazılı içerikler, konularına göre sınıflandırılmış ve alındıkları sosyal medya hesaplarının baş harfleri verilerek sıralanmıştır. Makalede öncelikle ağ toplumu kavramı üzerinde durulmuş; mizah ve internet ortamının siber mizah yaratma biçimi ele alınmıştır. Daha sonra bu kavramlar çerçevesinde kovid-19 salgını konulu siber mizah içerikleri analiz edilerek ağ toplumunun etkileşim tarzı değerlendirilmiştir.

\section{İnternet ve Ăg Toplumu}

Bilim ve teknolojinin 20. yüzyıldaki gelişme hızı, ulaşım ve iletişim alanında önemli sonuçlar doğurmuştur. Toplum hayatını her yanıyla etkileyen teknolojik gelişmeler, geleneksel zaman ve mekân algısını yeniden şekillendirmiştir. Bugün içinden geçilen süreçte teknolojiye dayanan sanayi devrimlerinden dördüncüsü, geleneksel kültürel yapılarını değiştirmektedir. "Küresel popüler kültür ve tüketim kültürü, hiper bağlantılı ve sürekli çevrimiçi sanal-dijital bağlamda ulusal ve yöresel gelenek kültürleri üzerindeki etkileri artırmaya başlamıştır" (Özdemir, 2019: 218). Bu süreçte teknolojinin gündelik hayata yansıdığı önemli noktalardan birisi bilgisayar kullanımı ve yaygınlaşmasıdır. Bilgisayar, öncelikle bilgi depolama ve kullanma biçimlerini değiştirmiş; daha sonra internetin kullanımı ve yaygınlaşmasıyla asıl iletişim devrimini başlatmıştır. 1969'da askerî amaçlarla geliştirilmeye başlanılan internet, hükümetlerin yönetim organizasyonu ve kıtalar arası ticarî faaliyetlerin işleyişinde kullanılmıştır. Kurumsal ve kişisel bilgisayarların yaygınlaşması, internetin kullanım alanlarını da genişletmiştir. Türkiye'de kişisel bilgisayarlar 1980'lerin ortalarından itibaren yaygınlaşmış ve 1990'lardan itibaren internet kullanımına başlanılmıştır (Saka, 2019: 4-8). Bu süreçte bilgisayarın gündelik hayata önemli etikeri olmuştur. Postman, Amerikan toplumunu; "acele ve dikkatsiz bir biçimde bilgisayarı kucaklamış" olarak tarif eder ve "insan mı bilgisayarı kullanıyor, bilgisayar mı insanı kullanıyor?" (Postman, 2006: 125, 26) sorusunu sorar. İnternetin toplum hayatına etkisi, taşınabilir bilgisayarlar, tabletler, akıllı telefonlar ve diğer mobil cihazların yaygınlaşmasıyla artar.

Türkiye'de söz konusu değişimin 1990'lardan itibaren hızlandığı görülür. Bilgisayar, telefon ve internet kültürel hayatın merkezine girmiştir. Akıllı telefonların kullanımının yaygınlaşmasıyla birlikte internet kullanımı artar ve yeni medya ortamları doğar. Akıllı telefon, tablet, dizüstü bilgisayar gibi mobil cihazların "taşınabilir" olması ve internetin sağladı̆̆ "yeni medya ortamlarının çeşitliliği”" bu cihazların kullanım alanlarını genişletir (Aktaş, Berk, 2013: 629-638; Dede 2014: 6371;). Bilgi Teknolojileri İletişim Kurumunun yayınlamış olduğu 2019 yılı 3. çeyrek pazar verilerine göre Türkiye'de; "Eylül 2019 sonu itibari ile 82.896.10813 mobil abone bulunmaktadır. Temmuz 2009'da sunulmaya başlanan 3G hizmeti, Mart 2016 sonu itibarıyla 65.949 .652 aboneye ulaşmış, ancak 1 Nisan 2016 tarihinde 4.5G'nin hayata geçmesiyle 3G aboneliğinden 4.5G aboneliğine hızlı bir geçiş süreci yaşanmıştır. Eylül 2019 sonunda 3G abone sayısı 4.959.802'ye düşerken 4.5G abone sayıs1 76.028.440'a çıkmıştır.”(Türkiye Elektronik Haberleşme Sektörü Üç Aylık Pazar Verileri, 58). Bu sayısal veriler, Türkiye'de internet kullanımındaki yaygınlığı ve her yeni teknolojiyle yaşanan hızlı değişim sürecini göstermektedir. Bilgisayarın bireysel kullanımından, taşınabilir mobil cihazlara geçiş ve bu cihazlarla internet teknolojilerinin sürekli güncellenerek yaygınlaşması, yeni bir toplumsal iletişim biçimini doğurmuştur. Bu süreçte internetin insan hayatını etkileyen işlevleri de belirleyici olmuştur. İnternetin işlevleri arasında "pratiklik, eğlenme yönelik olma, eğitsel ve kültürel” işlevlerin ön plana çıktı̆̆1 görülür (Sartori, 2004: 40). 
21. yüzyılda taşınabilir cihazlarla her mekânda erişilebilir bir bilgi veri ağı haline gelen internet, toplumu sarmal şeklinde etkisi altına almıştır. Bu durum, kültürel yapıları değiştirirken insanla bilgi arasındaki fiziksel ve zamansal mesafeyi de ortadan kaldırmıştır. Ancak bu bilgi biçimi yalnızca bilimsel değil; aynı zamanda her türlü içeriğin bir arada olduğu karmaşık bir veri yığını şeklindedir. İnternet çağı insanının bu yığını ayrıştırma ve kullanabilme becerisi, internetin sosyal, siyasal, ekonomik ve kültürel etki biçimini de şekillendirmektedir. Bu bilgi yığını karşısında insan "magazinsel" verilerin egemenliği altında kalabilir. Kitlesel kullanım biçimlerinde internet "seyirlik gösterilerin ve imajın, dolayısıyla görünürlüğün ve yüzeyselliğin öne çıkmasına" (Özdemir, 2012: 13-34) neden olur. İnternet, bir yanıyla bilgiyi görselleştiren ortamları sağlamasıyla toplumu etkilerken başka bir yanıyla da sosyal bağ anlayışını değiştirmıştır. Medya biçimi olarak radyo, sinema ve televizyon büyük ölçüde tek taraflı bir iletim aracı şeklinde çalışır. İnternet medyası ise sözlü kültüre benzer bir iletişim biçimini yeniden oluşturur. Anlık ve güncel etkileşim, kültürün sınırlarını değiştirir ve kültürü mekânsallıktan çıkarır. İnternet bir taraftan "bireyin ihtiyacı olan enformasyonu bulmasını" sağlarken bir taraftan da "çift taraflı iletişime imkân veren yapısıyla, insanların dostluklar kurmasına, paylaşımlarda bulunmasına, ilişkiler kurmasına ve geliştirmesine ve başka kültürlerden insanlarla etkileşime girmesine imkân" sağlar (Özdemir, 2012: 16).

İnternet toplumunun gündelik hayattaki kültürel üretim ve tüketim tarzlarını, dâhil olduğu sosyal ağlar şekillendirir. Dijital dünyada geleneksel "algılar, düşünceler ve düşünme biçimleri" sürekli değişim halindedir (Karadaş, 2015: 325-341). Yeni medya ortamlarında kurulan sanal sosyal bağlar, bugünün insanının yeni akraba, arkadaşlık ve özel hayat anlayışını etkiler. Siber kimliklerle kurulu bu ilişki biçimleri; zaman, mekân ve emek açısından daha az maliyetlidir. Ayrıca, istenildiğinde terk edilebilir, yenilenebilir ve "sıkıntıya gelmeden bolluk ve bereket serbestliği" vardır (Ö̈zdemir, 2012: 13-34). Sosyal medyanın sağladığı bu özgür alan, yüzeysel de olsa kültürel içeriklerin üretim ve tüketimi açısından serbestliği getirir. Sosyal medyanın etkisi, sanal ortamı aşarak gerçek hayata yön veren popüler kültürün üretim ve yaygınlaşma dinamiğine dönüşür. Bir yeni medya biçimi olarak sosyal medya, "geleneksel medyanın aksine sıfir maliyetle kullanılır, erişim imkânları daha kolaydır, kullanım bakımından basitlik arz eder ve üzerinde değişim kolay olduğundan sabitlik söz konusu değildir" (Vural, Bat, 2010: 3348-3382). Bugün, geleneksel medyanın yeni medyadan beslendiği ve oradan da kitleselleşerek her türlü bilginin sözlü kültür ortamına tekrar taşındığı tersine bir süreç işler. Binark'ın ifadesiyle, "geleneksel ve yeni medya ortamlarının iç içe geçtiği gündelik yaşamımızın içine gömülü olduğu yeni bir toplumsal eko-sistem" ortaya çıkmıştır (Binark, 2015: 9-18). Sosyal medya, "toplumsal, kültürel ve endüstriyel" bir olgu haline gelmiştir (Karaduman, 2017: 7-27).

Kültürel sınırların ortadan kalktığı enformasyon çağında, ağ toplumunun üyeleri sürekli etkileşim içerisindedir. Teknolojinin yarattığı değişim, "insan iletişiminin yazıll, sözlü, görsel-işitsel biçimlerini aynı sistem içinde bütünleştiren bir hipertext ve meta-dil” yaratır. Bu dilin kullanıldığı ağlar, toplumun "sosyal morfolojisini" oluşturur. Böylece "üretim, deneyim, iktidar ve kültür süreçlerinde işleyiş değişir.” Ayrıca bu sosyal ağlar, "dijital, görsel-işitsel hipertext'in kapsadığı kod ve değer çeşitliliği içinde izleyicilerle etkileşimde olan, izleyicinin de etkileşim kurduğu" ortamlardır (Castells, 2008: 440, 621, 630). Bu süreçte kültürel gerçeklik kavramı yeniden sorgulanır ve kültür, içinden geçtiği elektroniğin yapısına göre şekillenir. Sözlü kültür geleneğinin yazıyla yorumlanma süreci; işitsel, görsel iletişim sistemleriyle yeniden güncellenir.

A ̆ toplumunda birey, ağa dâhil olmaya çalışırken yeniden bir kimlik oluşturur. Bireyin yeni teknoloji toplumunda kültürlenme biçimleri ve kimlik kazanması, geleneksel süreçlerden farklıdır. Geleneksel toplum yapısında birey kültürün öznesiyken, yeni sistemde hem özne hem de nesne konumundadır. Dijital iletişim ortamının kimlik biçimleri, geleneksel kültürel yapıların aksine statik değil, dinamiktir. Diğer taraftan "kimlik, günümüzde hâlâ görece sınırları çizilmiş kalmakla birlikte eskiye oranla katı halden çok daha kırılgan ve esnek hale gelmiştir" (Erdinç, Can, 2018: 39-47). Kimlik oluşumundaki bu esneklik, bireylerin ağ toplumunda kendini gizlemesi veya dönüştürmesi 
yoluyla ürettiği değişken kimlikleri kullanmasını sağlar. Klinik psikoloji alanında yapılan çalışmalarda "siber alter" kişilik kullanımının sebepleri çeşitli yönlerden ele alınır ve bu durumun en önemli nedeninin "yoğun travmatik geçmiş" olduğu ifade edilir (Erdinç, Can agm). Geçmişten kaçan birey, siber alter kişilikle ağ toplumunda "kopya hayatlar" yaşar. Yeni kültür çevresinde ortaya çıan kronik problemlerden birisi de bireyin dijital ağ toplumuna üyeliğine bağımlı hale gelmesidir. Bilgisayarın bireysel kullanımının yaygınlaşmasıyla ortaya çıkan teknoloji bağımlılığı, mobil iletişim teknolojilerinin yaygınlaşmasıyla daha ileri düzeye taşınır. Tedavi gerektirecek kadar ileri aşamalara ulaşabilen bağımılılığın ortaya çıkmasında, internet ortamının kişiyi gerçek hayatın sıradanlığından çıkarması ve "zaman ve mekân arasındaki ilişkiyi yapı bozumuna uğratması" etkili olmaktadır (Kırık, 2013: 98; Karagülle, Çaycı 2014: 1-9).

Teknoloji çağında fiziksel gerçeklikte yalnızlaşan insan, internetin oluşturduğu sosyal ağların "simülasyon" (Baudrillard, 2014) gerçekliğinde var olmaya çalışır. Böylece, "kaynakla alıcının etkileşim içerisinde olduğu interaktif iletişim ortamında" kendi gerçekliğinin dışında yeni iletişkiler kurabilir (Göker, Doğan, 2011: 180; Aktaş, Berk, 2013: 629-638). Diğer taraftan çevrim içi ortamlar, kişilerin mevcut etkileşim biçimlerini destekleyebildiği gibi, toplumsal soyutlanma ve parçalanmaya da neden olabilir (Denizci, 2009: 47-63). Buradan hareketle, iletişim teknolojilerinin yarattığı ağ toplumunda, uzaktaki yakınlar ve yakındaki uzaklar paradoksunun ortaya çıktığı söylenilebilir. Dolayısıyla gündelik hayat, içinde bulunulan fiziksel çevreyle birlikte, uzaktaki yakınlarla paylaşılan, etkileşilen ve sürdürülen bir boyut kazanmıştır.

\section{Yeni Kültür Ortamında Mizah}

Geleneksel bilgi aktarım sistemlerinin değişmesi, kültürün yaratım ve paylaşım biçimlerini yeniden şekillendirmiştir. Yazı sonrası dönemde iletişim teknolojilerindeki gelişmeler, kültürel yapıların yeni iletişim biçimine uyum sağlamasını zorunlu kılmıştır. Sözlü kültür ortamında, belleğe dayalı kayıt sistemleri vasıtasıyla dolaşımda olan kültürel birikim, yazılı ve elektronik kültür ortamlarında yeni formlar kazanmıştır. Elektronik kültür ortamı, insan zihninin çalışma, üretme ve paylaşma biçimini yeniden şekillendirmiştir. Tarihsel süreçte insanın, fizikî ve sosyal çevresine verdiği kültürel tepkiler, elektronik kültür ortamında sanal içeriklere dönüşmüştür. Oluşan dijital ekolojide interaktif iletişimle insan kendi eğlence, vakit geçirme, eğitim ve etkileşim biçimlerini geliştirmektedir. Geleneksel kültürde önemli işlevleri olan mizah, yeni kültür ortamının yazıll, işitsel ve görsel ögeleriyle üretilerek ağ toplumunun eğlence ve eleştiri araçlarından birisi olmuştur.

Mizah, Türkçe sözlükte "gülmece" olarak karşılanır ve "1. Eğlendirme, güldürme ve bir kimsenin davranışına incitmeden takılma amacını güden ince alay, mizah, humor. 2. Gerçeğin güldürücü yanlarını ortaya koyan edebiyat türü, mizah, ironi.” (Türkçe Sözlük, 2011: 999, 1692) olarak tanımlanır. Sözlü kültür ortamında önemli işlevleri olan halk mizahını Türk sözlü kültürü içerisinde "temsil eden en estetik yapı fikradır" (Yıldırım, 1999: 3, 8). Gülme ve mizah konusu insan fizyolojisini ve psikolojisini anlamaya çalışan pek çok bilim alanının gündeminde olmuştur. $\mathrm{Bu}$ kapsamda yapılan çalışmalar mizah teorilerini şekillendirmiştir. Mizah teorileri üstünlük, rahatlama ve uyumsuzluk (zıtlı) teorisi şeklinde sıralanır (Morreall, 1997; Feinberg, 2004: 105-113; Türkmen, 2013: 43).

Bugün, "sözlü, yazıl1, görsel-işitsel ve internet ortamında üretilip tüketilen mizahın" tarihsel süreçte çeşitli bireysel ve toplumsal işlevler üstlendiği görülür (Çetin, 2019: 534). Eker'in ifadesiyle mizahın, "horgörüden hoşgörüye, gülümsemeden alaya, işkenceden tedaviye" kadar uzanan çeşitli mizyonları olup "21. yüzyılda iyileştirme, yararlılık, rahatlama, mutluluk verme, organize etme, hayata tutunma" gibi işlevleri vardır (Eker, 2009: 230, 55). Mizaha olan bakış geçmişten bugüne negatiflikten pozitifliğe doğru dönüşmüştür.

Mizahın bir göstergesi olarak gülme, yapılan çalışmalarda çeşitli yönlerden ele alınmıştır. Koestler "Mizah Yaratma Eylemi"nde gülmeyi bir "tepke" olarak tanımlar (Koestler, 1997: 6). Gülmeyle ilgili yapılan tespitlerde gülmenin, "ani psikolojik değişiklikte memnuniyetin ifadesi”" 
olduğu söylenir (Morroal 2003: 435). Öte yandan "mizahın en etkili öğesi olan gülme, kişinin görsel ve işitsel uyarıcıyı komik bulması sonucu gerçekleşen bir eylem olmakla beraber; gösterge olarak kullanılan nesne, olay, mekân, durum gibi mizah eyleminin bileşenleri, her zaman mutluluğu ve olumluluğu simgelemez." (Eker, 2009: 54). Sanders,'ın ifadesiyle gülme, ateşin tutuşması gibi hızı gösterir. Havayı hızlıca çekerek "canlanmayı" sağlar ve "beklenmedik bir utkudur" (Sanders, 2001: 313). Bergson ise gülmeyi bulaşıcı bir eylem olarak yorumlar. Ona göre gülme "yankılanmaya ihtiyaç duyar gibidir" (Bergson, 2014: 6). Herhangi bir sosyal ortamda gülme, bulaşıcı bir eylem olarak herkesi etkisi altına alabilir. Gülme durumunun ortaya çıkmasını sağlayan mizahî özne insandır. "Mizahî ("humorous") insan belirsiz, kendine özgü -kestirilemez- şekilde davranan insandır." (Sanders, 2001: 120). Bu belirsizlik mizah olgusunun karmaşıklığıyla ilgilidir. "Mizah, yüksek karmaşıklık düzeyindeki bir uyarının, fizyolojik tepkeler düzeyinde büyük ve kesinlikle belirlenen bir tepki yarattığı tek yaratıcı eylem alanıdır" (Koestler, 1997: 10). Koester, mizah çeşitlerini; "sözcük oyunları ve nüktecilik, insan ve hayvan, kişileştirme, çocuksu yetişkin, önemsiz ve yüceltilmiş, karikatür ve yergi, uygunsuzlar, kırkayak paradoksu, kaydırma, rastlantı, saçma, gıdıklama, palyaço, özgünlük, vurgu, tutumluluk" şeklinde sıralar (Koestler, 1997: 57-91).

Elektronik kültür ortamı, mizahın etki alanını genişletmiştir. Sosyal medyayı kullanan ağ toplumunun üyeleri, mizahın "birleştirici ve entelektüel yanını" kullanarak ortak tutum geliştirebilir (Arslan, 2014: 267-277). Böylece sosyal medya, mizahın üretildiği ve yayıldığı güncel ortama dönüşür. Arslan bu konuda şu tespiti yapar:

"Sosyal medyada üretilen mizah unsurlarının kendine has bir dili olması, kullanıldığı ortama göre şekil değiştirmesi, paylaşılarak çoğalması ve yeniden üretilmesi yani güncellenebilirliği, üretilen profile ve ürüne göre anonim özelliği göstermesi ve internet bulunan her ortamda her an kolay ulaşlabilirliği, sosyal medya mizahının ortak noktalarını oluşturmaktadır. Özellikle sosyal platformların birbirileriyle iç içe geçmişliği tek bir üyelik sistemiyle diğer bütün sitelerden yararlanmalarını sağlamaktadır” (Arslan, 2017: 22-38).

Sosyal medyada üretilen mizah, genellikle güncel olaylardan beslenir. Mizahı üretip dolaşıma sokanların bir kısmı profesyonel üreticilerdir. İnternet trollerinin mizah üretirken çoğunlukla "güncel olayları, cinsel unsurları, kültürel deneyimlerin getirdiği geleneksel davranış ve ifade biçimlerini ve internet fenomenlerini ele aldıkları görülür" (Özay, 2018: 409-420). Bu üretim tarzında geleneksel mizah belleğinden de yararlanılır. Yaratıcı sosyal medya mizahında görsellik ön plandadır. Bu mizah biçimi, ulaşımı ve katılımı kolay olan sosyal ağlarda dolaşıma girer. Gündelik hayatın uyumsuz, saçma veya gülünç yanları eğlence unsuruna dönüşebilir. "Kullanıcılar, tüketicilerin daha güçlü olduğu medya ortamında üre-tüketici olarak sosyal medyada kendi kültürünü yaratmaktadır. Kimi zaman ince bir mizahi nitelikte, kimi zamansa estetik ve incelikten uzak olarak üretilen sosyal medya mizahı, popüler bir üretim yöntemi olarak içinde bulunulan teknoloji çağında iletişimin dönüşümünü göstermesi açısından önemlidir" (Kırık 2017: 99-118). Dijital çağda bilgi, içinden geçtiği teknolojiye göre şekil alarak çeşitli yollarla üretilir ve "internet sitelerinden şarkı sözlerine, roman, hikâye gibi edebi eserlerden siyasete kadar 21. yüzyıl teknolojisinin donanımıyla farklı renk ve görüntülere büründürülüp" sunulur (Eker, 2009: 230; Çetin, 2019: 533). Mizah unsurları bu kültürel süreçlerin parçası olarak şekillenir. Birey, sözlü kültür ortamının anlık ve doğal tepki biçimlerine benzer şekilde kendi mizahını üretir ve sosyal ağlar üzerinden dolaşıma sokar.

Sosyal medya kullanım biçimlerinde yaş gruplarının önemli etkisi vardır. Üretilen mizahın yapısı ve içeriği hem ülke hem de dünya gündemini yakından takip eden aktif nüfusa bağlı olarak değişmektedir. Diğer taraftan sosyal medya uygulamalarının kullanım oranları da dolaşımdaki kültürel içeriklerin yapısını şekillendirmektedir. 2020 Türkiye İnternet Kullanımı ve Sosyal Medya İstatistiklerine bakıldığında; sırasıyla YouTube, Instagram, WhatsApp, Facebook ve Twitter uygulamalarının popüler olduğu görülür. Türkiye'de sosyal medyanın en yüksek kullanım oranı 2534 yaş aralığındadır (Url 1). Bu uygulamalar görsel ve işitsel içeriklerin üretim ve tüketimine olanak sağlamaktadır. 


\section{Mizah Virüsü Olarak Kovid-19}

Kovid-19 olarak adlandırılan virüsün ortaya çıkması ve Türkiye'de görülmesi sosyoekonomik hayatın gündemini değiştirmiştir. Resmî kurumların virüsün Türkiye'de yayılmasını önlemek amacıyla aldığı önlemler, gündelik hayatın her alanına yansımıştır. Sağlık Bakanlığı Halk Sağlığı Genel Müdürlüğünün resmî web sayfasındaki bilgilere göre; yeni corona virüsü (kovid-19), ilk olarak Çin'in Vuhan Eyaleti'nde 2019 yılı aralık ayının sonlarında ortaya çıkmıştır. Virüs, solunum yolu belirtileri (ateş, öksürük, nefes darlı̆̆ı) gelişen bir grup hastada yapılan araştırmalar sonucunda 13 Ocak 2020'de tanımlanmıştır. Salgın, başlangıçta bu bölgedeki deniz ürünleri ve hayvan pazarında bulunan insanlar arasında tespit edilmiştir. Daha sonra insandan insana bulaşarak Vuhan başta olmak üzere, Hubei eyaletindeki diğer şehirlere ve Çin Halk Cumhuriyeti'nin diğer eyaletleri ile dünya ülkelerine yayılmıştır. Korona virüsleri, hayvanlarda veya insanlarda hastalığa neden olabilecek geniş bir virüs ailesidir (Url 2). Sağlık Bakanı Fahrettin Koca'nın yapmış olduğu açılamayla 11 Mart 2020'den itibaren Türkiye'de vakaların görüldüğü ilan edilmiştir (Url 3). Virüsle ilgili haberlerin ortaya çıkmaya başlamasıyla birlikte, sosyal medyada konuyla ilgili paylaşım ve yorumlar artmışır. Sosyal medya ortamlarında virüsle ilgili verilen tepki öncelikle mizahî boyutta olmuştur. Konuyla ilgili mizah içerikleri, geleneksel medya olarak tanımlanan gazete ve televizyondan ziyade, yeni medyanın bir parçası olan sosyal ağlar üzerinden yayılmıştır. Sosyal ağlarda, gündelik olayları algılama ve verilen tepkiler bireyseldir. A $\breve{g}$ toplumunun üyeleri, konuyla ilgili hem ürettikleri hem de dolaşımda olan güldürü unsurlarını paylaşarak konuya olan tavırlarını ortaya koymuşlardır. Bu yolla bir mizah ağı oluşmuştur. Çalışmada bu durum, dijital ortamının etkileşim tarzına dayanarak siber mizah yaratma biçimi olarak yorumlanmıştır.

Dijital ortamda üretilen mizah içeriklerinin belirgin özellikleri, "yazılı, işitsel, görsel, görselişitsel mizah" şeklinde kümelenir (Özdemir, 2009: 1277-1301). Bunun yanı sıra, iletişim teknolojilerinin olanakları, içeriklerin birden çok özelliği taşıyabilmesini sağlamaktadır. Yazılı bir mizahî unsur, görsel bir içerikle birlikte; işitsel-görsel bir içerik, yazıyla yorum veya ifade eklenerek dolaşıma sokulabilmektedir. Sosyal medyada üretilen mizah unsurlarının beğenilmesi ve sık paylaşılmasında, paylaşan kişinin eleştirel bakış açısı ve konuyla ilgili tutumu etkilidir. Üretilen veya paylaşılan mizah içeriğine yazıyla eklenen yorum ya da emoji, kullanıcının tavrını yansıtır. Korona virüsü konusunda üretilen işitsel mizah örneklerinin WhatsApp gruplarında dolaşımda olan ses kayıtları olduğu görülmüştür. Bu çalışmada konuyla ilgili olarak Facebook, Twitter, Instagram ve YouTube'daki akış üzerinden yapılan paylaşımlar taranmıştır. Çalışmada çoğunlukla hesaplar metinde kaynak olarak gösterilmemiş, örneklerin alındığı sosyal medya hesaplarının adları kısaltılarak verilmiştir. Görsel içerikler ise taramalarda karşılaşılan herkese açık hesaplardaki en fazla dolaşımda olan mizahî içeriklerden seçilmiştir.

Korona virüsü konusunda üretilen mizah içeriklerinin bir kısmının kişilere ait hesaplardan paylaşıldığ 1 görülürken bir kısmının ise, doğrudan korona/corona adı kullanılarak açılan veya adı korona/corona olarak değiştirilen hesaplar üzerinden yapıldığı tespit edilmiştir. Instagram ve Twitter'daki korona/corona adı kullanılan hesap örneklerinden bir kaçı şunlardır: coronamizah, coronakomedi, corona_mizahyhf, coronamizah1, corona_mizah, corona.mizah, corona.mizah., mizahcorona, corona_mizah.yedek, coronavirüsmizah, coronalimizahsor, mizahitizasyon, prof.dr.corona, mizahofcovid, Covid19 Tr Şubesi, Corona Günlerinde A.

Korona virüsü konulu yazılı mizah örneklerinin çoğunlukla Instagram ve Twitter'da dolaşımda olduğu tespit edilmiştir. Özellikle Twitter'daki paylaşımların altına da benzer şekilde çok sayıda yorumun yapıldığı görülmüş̧ür. Ağ toplumunun mizah yaratma örneğinde anlık iletişim ve tepki biçimi yorumlarda da devam etmiştir. Korona virüsü gündemiyle yapılan yazılı paylaşımların, gündelik hayat, iş, temizlik, karantina, yiyecek ve eşya stoğu, eğitim-öğretim süreçleri gibi konularda olduğu görülmüş̧ür. Ayrıca bazı paylaşımlarda yazıyla birlikte görsel içerikler de kullanılmıştır. Konuyla ilgili paylaşımlardan alınan örnekler şu şekildedir: 


\section{Yazılı Mizah İçerikleri}

\section{Salgin}

TDK: Şu andan itibaren, "Coronavirüs" yerine Türkçe karşıllğg "Gıran Giren" olan sözcüğ̈̈müzü kullanacağız. Duyanlar duymayanlara çok hızl bir şekilde söylesinler.

M: Arkadaşla maske almaya gittik (Karadenizli) maskeyi taktı diyor ki bunun bir beden büyü̆̆̈̈ yok mu? Burnuma küçük geldi.

N.K: Korona zengin fakir ayırımı yapmıyor. Din, dil, ırk ayırımı da yok. Tam bir gomonist uygulama Çin'de eğitim aldiğı belli.

Y: 400 milyar çekirge Türkiye'ye gelmekten vazgeçti. Irran'a doğru geçiş yaptılar. Bu millet bu zor günde yaptığınız iyiliği asla unutmayacak.

Çekirge adlı hesap: Hangi şehirden girmeye başlasak acaba?

R: Corona Türk olsaydı nereli olurdu?

M: Karantina olursa pencereden hangi şarklyı söyleyeceğiz?

-P: Bir ihtimal daha var o da ölmek mi dersin.

B: İtalya'da Coronadan dolayı sokağa çıkma yasağı olunca İtalyanlar balkona çıkıp şarkı söylediler. Aynısı Türkiye'de olsa hangi şarklyı söylerdiniz?

K: Kanser alkolü terk ettiriyor, Korona alkole başlattyor. Hikmetinden sual olmaz Allah'ım.

$\mathrm{N}$ : Şu anda virüsün Türkiye'de nasıl yaylldı̆̆ Instagram storylerinde net biçimde görülebilir.

K: Italya her an koronanın tarafina geçebilir. 1. ve 2. Dünya Savaşında olduğu gibi.

Corona: Ne yapacaksınız, sokağa mı çıkmayacaksınız? Hahaha.

P: Corona bir burç olsaydı hangisi olurdu?

C: Gratisi de kapattırdım kuzlar, şimdi gerçek yüzleriniz görme vakti.

$\mathrm{N}$ : Corona virüse bir şey söyleme hakkınız olsa ne derdiniz?

Corona: Korkmayın sadece tiktokçuları alıp gideceğim.

C: Aranızdan kimi almamı istediğinizi etiketleyin.

C: Fenerbahçeliler korkmasın onlara bir şey yapmayacağım. Zaten benden beterler.

C: Istanbul hareketlerine dikkat etsin.

C: Adana nerede?

C: Bakan Bey çok zorluk çıkarıyorsunuz, yayılamıyoruz.

C: Boğazında kuruluk hissedenler FAV.

C: İkizler burcu olanlar sizleri unuttum sanmayın.

I: Korona riskinden evde okunduğunda sizleri koruyacak 14 kitap.

A: Coronaya karşı bir milli birlik mitingi, şöyle dosta düşmana karşı Yenikapı'da.

C: Kuzey Kore'den hizlı önlem: Enfekte olan iki kişi idam edildi.

C: Allah'im sence çok üstümüze gelmiyor musun?

A: Korona virüsüne karşı 4-5 diş sarımsak ve 1-2 başs soğan yiyin. Hiçbir faydası olmaz ama en azından herkesle güvenli bir mesafede olursunuz. (-)

Ç: Öğrenciye ev vermeyen amcaların ögrenci yurtlarında karantinaya alınması, Flash TV Gerçek Kesit bölümü gibi.

İ: İktisat uzmanları, beslenme uzmanlarl, Suriye uzmanları ve korona virüsü uzmanları aynı kişiler.

\section{Temizlik-Kolonya}

A: Kolonya giren eve doktor girmezmiş.

S.: Herkes babam kokuyor bu ara. I love limon kolonyast.

Corona Türkiye: Size kolonyayla öldügüumü kim söyledi?

Corona: Ben gelip geçiciyim, içinizde mikroplara dikkat edin.

C: Arap sabunuyla yoğurdu karıştırıp yerseniz ben size ulaşmadan zaten siz kendi kendinizi imha etmiş olursunuz. 
C: İki yüzlü insanların iki tane maske takması lazım korunabilmesi için.

Son Dakika: Eyüp Sabri Tuncer Apple'ı almak için teklif vermeye hazırlanıyor.

C: Peki sana bulaşmamam için ne yaptın?

KMY: Insanlar ne arlyordu?

M.Ö 1: Akll

M.S 1: Yiyecek

1200: Şöhret

1300: Sağllk

1500: Kita

1700: Özgürlük

1800: $\dot{I}_{\text {şçi }}$

1900: Petrol

2019: Priz

2020: Kolonya

A: Uçakta yanımda oturan Polonyalı çift tarçınlı kolonyayla şov yapıyordu. Ta ki ben Tariş'in zeytin çiçeği kolonyasını çantamdan çıkarana kadar. Herkes nerden diye sordu. Siz görürsünüz Ege'nin yumruğu nasll patlar beyninizde.

B: Markete kardeşimi yolluyorum.

M: Adliyeye stajyerimi gönderiyorum.

A: Ayda bir banyo olurken haftada bire çıkardım.

A: Etil alkol çaldım okuldan yarım litre.

\section{Ĕ̆itim-Öğretim}

B: Coronavirüsü dünyanın sonunu getirecek mi? Ona göre sınavlara çalışacağım.

$\mathrm{H}$ : Coronavirüsü dünyanın sonunu getirecek mi? Ona göre yks çalışacağım.

A: Corona günlerinde tez.

T: Virüsten önce veli: Ögretmenler de hiçbir şey yapmıyorlar, yatarak para kazanıyorlar. Virüsten sonra çocuğuyla 1 saat ders yapan veli: Öğretmen maaşı Amerikan başkanının maaşına eşitlenmeli.

C: Sevgili ögrenci kardeşlerim, size kimsenin yapamadı̆̆ını ben yaptım.

T: Bu sene mezun musun diyen herkese çok büyük bir sorun olmazsa evet mezunum dedim. Çok büyük bir sorun oldu.

Akademik Dedektif: Evdekilerle konuşacak laf bitti, tez konumdan bahsediyorum.

\section{Karantina ve Umreciler}

S: Umreciler, ilk sene yurtta kalırsınız, ertesi sene kafa dengi arkadaşla eve çıkarsınız.

$\mathrm{H}$ : Umreden gelenlere KYK mı çıkmış?

T: Yaşlılar KYK'de kalıyor. Gençler evde emekli hayatı yaşıyor. T.C. simülasyonu şaşırtmaya devam ediyor.

N: Keşke KYK yurtlarından karantina süresince canlı yayın yapsalar, biri bizi gözetliyor gibi tüm gün evde oturup dayıların tartışmasın izlesyip gün sonunda sms ile oy versek, kazanan hacı karantinadan çıksa. (Yorumlardan birisi: Haclık Oyunu).

A: Marmara Üniversitesi cıvarı özel yurt var mı bildiğiniz? Dedeme KYK çımamış.

E: Geçen hafta birisi önümüzdeki 500 yll boyunca yaşanmayacak bir olay söyle dese; ögrenci yurdunda karantinaya alınmış yaşlı umrecilerin yurttan kaçmak için polisle çatışması diye yanitlardim.

A: Twitter bireyi tamam evden çımaz da Instagramciyı nasıl tutacaksınız? Devlet instagramı kapatmalı. 


\section{Stokçular}

T: Sabun ve kolonyanın hepsi sende olursa korunamazsin, herkeste olursa korunursun. (-)

Ü: Arkadaşlar yanlış yerde bağırıp duyuru yapıyoruz. Hep birlikte facebooka geçmemiz lazım hedef kitle orada.

Sosyal medyada üretilen korona virüsü konulu yazılı mizah içeriklerinde virüsün gündelik hayata etkisi görülür. Bu süreçte özellikle Twitter kullanıcılarının güncel olayları takip ettiği ve anlık tepki geliştirdiği söylenilebilir. Bu tepkiler bir yandan gülme unsuru taşırken bir yandan da eleştiri mahiyetindedir. Virüsün Türkiye'de yayıldığı ve kontrol altına alınmaya çalışıldığı süreçte insanların hijyen, karantina ve stok yapma konularındaki özensizlikleri sosyal medyada mizaha konu olmuştur.

Korona virüsü konulu yazılı mizah içerikleri hem sosyal medya ağlarında hem de çeşitli internet sitelerinde üretilmiş ve paylaşılmıştır. Virüsün etkilerine ve sonuçlarına gönderme yapacak şekilde internet ortamında yazılan şiirler, özellikle Facebook ve Twitter'da dolaşıma girmiştir. A $\breve{g}$ toplumu üyeleri arasında yaş, cinsiyet, eğitim durumu ve sosyo-ekonomik statü farkı azalır. Aynı sosyal ağ üzerinden her kesimden insan etkileşime girebilir. Sosyal medyada toplumun her kesiminden insanın gündelik olaylar karşısındaki tepkilerini görmek mümkündür. Bu bağlamda akademisyenlerin de korona virüsünü konu alan yazdıkları mizah içerikli şiir ve diğer metinleri sosyal medyada paylaşıkları görülür. Bu paylaşımlar yoğun ilgi görmüş ve dolaşıma girmiştir. Bu kapsamda Prof. Dr. Öcal Oğuz, "Korona” başlığıyla yadığı şiiri Facebook hesabından paylaşmıştır:

\section{KORONA}

Teslim oldu çaresiz

Ateş ona kor ona

Çıngı saçtı od yaktı

Evler yıktı Korona

Kimde ise vebali

Öte taraf zor ona

Aymaz gitsin Niğde'ye

Çoktan geçti Bor ona

Keyfimiz yok İtalya

Katılmaya korona

Firsat arar sömürgen

Ne kazanır sor ona

İnsan olan utanır

As1l bunlar kor ona (E. T. 17.03.2020)

Bir diğer örnek Prof. Dr. Ozan Yılmaz'ın Facebook hesabında paylaşılan "Gazel-i Koronây1 Pür-Cinâs Berây-1 Kurenâ-yı Semptom-Şinâs" başlıklı, aruzun fâ'ilâtün / fầ'ilâtün / fầilâtün / fầilün kalıbıyla yazılmış "koruna" redifli gazelidir:

İster isen el yusun cân sağlığından korona

Maske tak u el yıka çıkma evinden koruna

Her kim olmaz bu nasîhatten melûl ü muntasıh

Çîn ü Mâçîn'i aşıp korona korlar kor ona

Garb'ı alıp etkisine Şark'1 etti tamtakır

Fabrikalar kapatırken dayanır mı kur ona

Hind ü Îrân Çîn ü Kore korkudan hep bembeyâz

Amerika hangi yüzle âmbargo kor una

Torino Roma Milano'dan çekilmiş el ayak

Çeşme-i Aşk'ın dibine gel de at bir koruna 
Târumâr olmuş sanırsın bir yarasa görmesin

Barselona Kartagena Madrid ü La Koruna

Kim kaparsa bu virüsü âteşîn te'sîr olup

Mevsimin tüm soğuğunda karlar olur kor ona

Hem havada hem denizde hem karada yolcuyu

Tez karantinaya alıp iletişim kuruna

Ölmeden evvel ölüp pek korkar ise hastası

Doktoru alttan alıp çok yapmalıdır kur ona

Hâne halkından birisi olmasın dersen marîz

Evde dursun kıy parana Netflix'i kur ona

Ey Husûsî sen de manzûmenle çektin dikkati

Şimdiden sonra ahâlî cümleten hep koruna (E. T. 27. 03. 2020)

Uludağ Üniversitesi İlahiyat Fakültesi Öğretim Üyesi İlahiyat Prof. Dr. İbrahim Gürses'in Twitter hesabından yaptığı paylaşım bu konuda verilecek bir diğer örnektir: "Corona Virüsten sonra artık bir abdestle üç dört vakit namaz kılma devri sona ermiştir. Namazdan önce alınmış taze abdestle namazlarınızı kılınız. Hatta abdestiniz varsa bile yeniden abdest alıp öyle namaz kılınız." (E. T. 15.03.2020).

\section{Görsel Mizah İçerikleri}

Bu çalışma kapsamında Facebook, Twitter ve Instagram'da yapılan taramalarda korona virüsüyle ilgili en fazla görsel mizah unsurlarının paylaşıldığı tespit edilmiştir. İletişim teknolojilerinin ortaya çıkardığı dijital ortam, sosyal medya kullanıcılarına interaktif bir iletişim sağlamıştır. Birey bu ortamda "üretici, tüketici ve aktarıcıdır" (Gençalp, 2019: 52-75). Korona virüsü konulu üretilen içeriklerde sosyal medya kullanıcılarının karikatür görselleriyle birlikte yaygın olarak capsleri de kullandıkları görülür. Hazırlanan capslerde ünlü kişilerin, bilim adamlarının veya bir film sahnesinden alınan fotoğrafın trollenerek kullanıldığ 1 gibi; doğrudan durumun fotoğrafi üzerine ifade eklenerek de oluşturulabilmektedir. Çalışmada örnek olarak alınan görsel içerikler, herkese açık olan sosyal medya hesaplarındaki paylaşımlardan seçilmiştir. Üretilen bir içeriğin paylaşım sıklığı ve dolaşımda olduğu sosyal medya kanallarının çeşitliliği, içeriğin benimsendiğini gösterir. İçeriği paylaşan kişiler, bunun yarattı̆g duygu ve düşünce durumuna olumlu veya olumsuz tepki ekleyerek içerik üzerinden etkileşime girmişlerdir. Bir görsel içerik Facebook, Twitter ve Instagram'da aynı anda dolaşımda olabilmektedir. Konuyla ilgili alınan görsel içeriklerin yazılı mizah içeriklerinde olduğu gibi belirli konulara odaklanarak üretildiği tespit edilmiştir. Bu konular, virüs ve etkileri, temizlik-kolonya, eğitim-öğretim süreci, karantina ile yiyecek ve çeşitli gereçlerin stoklanması şeklinde sıralanabilir. Görsel içeriklerin güldürü ve eleştiri yönü ön plandadır. Konuyla ilgili seçilen görseller şu şekilde analiz edilmiştir:

\section{Salgın}

Görsel 1'de pazarcının içinde bulunduğu durum, bir mani ile anlatılmıştır. Korona virüsünün Çin'de ortaya çıktığı ve Çinlilere yedikleri yarasalardan bulaştı̆̆ konusundaki haberler, sosyal medyada yaygın olarak görülmüştür. Buna tepki olarak pırasa satan pazarcıyla ilişkilendirip "pırasa, yarasa, piyasa" kelimeleri kullanılarak mani yazılmıştır. Görsel 2' deki şalgamcı örneği, yaratıcı siber mizahın gerçek hayata yansıması olarak değerlendirilebilir. Şalgam suyu, özellikle Adana ve çevresinde yaygın olarak tüketilen bir içecektir. Seyyar şalgam aracının arkasına "Korona virüsü aşısı bulundu. Bir bardak şalgam bağışıklık sisteminizi güçlendirir." yazısı asılarak virüs ve ona karşı 
bulunmaya çalışılan aşı konusu, yapılan işle ilişkilendirilmiştir. Halk hekimliği bağlamında şalgamın sağaltıcı yönüne işaret edilir. Gündemin yapılan işe bir diğer yansıma örneği olarak Görsel 3 'teki dolmuş şoförünün dolmuşa maske taktığı paylaşımdır. Maske takmanın önemine dikkat çekme amacı bulunan bu örnekte, mizahın farkındalık aracı olarak kullanıldığı görülür. Özellikle Twitter'da paylaşılan bu görselle birlikte yapılan yorumlar da güldürü unsuru taşımaktadır. Paylaşımlardan birisinde; B.: "ilk realist roman: Recaizade Mahmut Ekrem Araba Sevdası" üst yazısı kullanılmıştır.

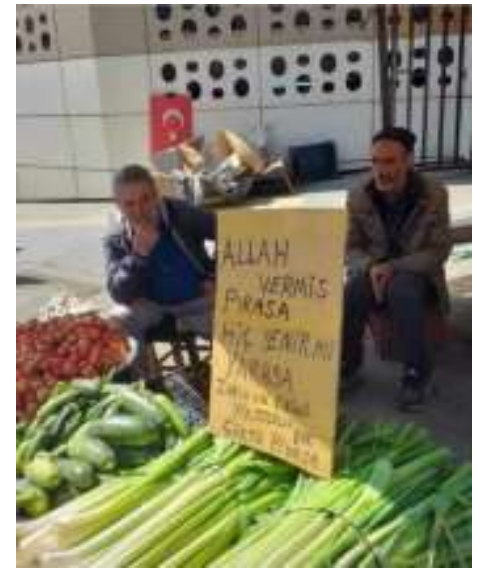

Görsel 1

(https://twitter.com/isosyalada $\mathrm{m} / \mathrm{status} / 12427495641904373$

79/photo/1 E. T. 25.03.2020)

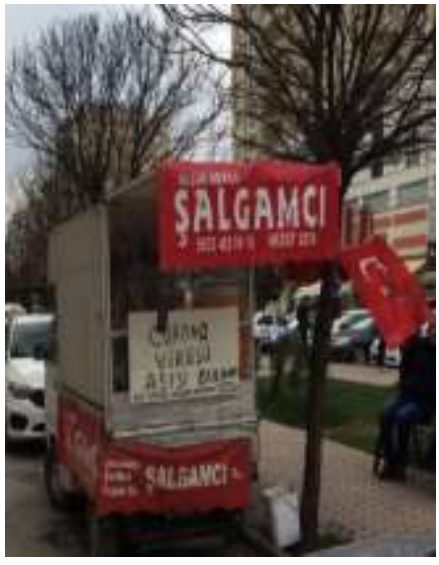

Görsel 2

(https://twitter.com/nedemeksak irlan/status/1270373403858554 881/photo/1 E. T. 09.06.2020)

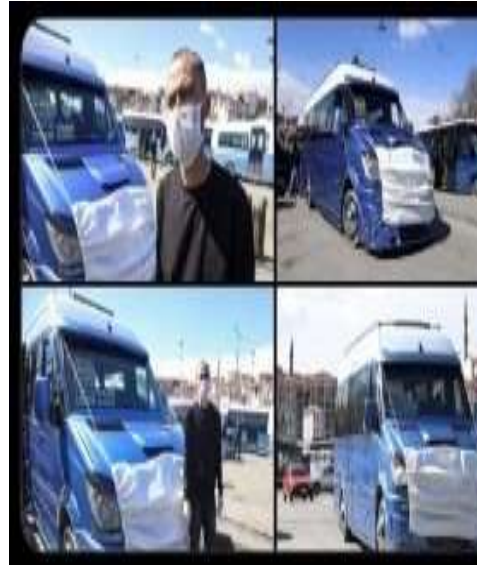

Görsel 3

(https://twitter.com/Biz10TV /status/12401733271651287

04/photo/1 E. T. 18.03.2020)

Yazılı olarak "mutlu bir adamın itirafı" başlığıyla oluşturulan ve sosyal medyada farklı biçimlerde dolaşan Görsel 4, iç içe geçmiş siber mizah örneklerinden birisidir. Yazılı içerik görsel içeriğe dönüştürülmüştür. Sosyal medyada dolaşımda olan en yaygın mizah içerikleri karikatür ve capslerdir. Profesyonel kişiler tarafından üretilen karikatürler, tüketici tarafından benimsendiğinde paylaşılarak dolaşıma girer ve yaygınlaşır. Görsel 5'te medyanın tavrına dikkat çekilerek mizahın eleştiri boyutu kullanılmıştır. Özellikle geleneksel medyada haber programlarında çarpıcı haber yaratmak için olayların sunuluş biçimi bazen abartılıdır. Görsel 6'da resmî karşılama törenlerine gönderme yapılarak hazırlanan bir karikatür örneğidir. Virüse karşılama töreni düzenlenmesiyle, özellikle yeni duyulmaya başlandığı sırada, kamuoyunun verdiği tepkilere gönderme yapılmıştır. 


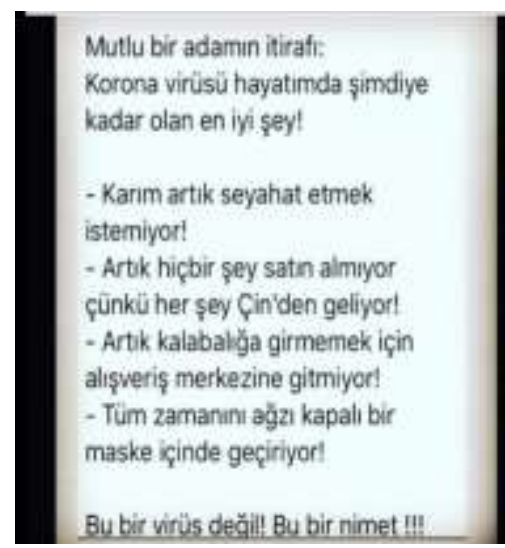

Görsel 4

(https://www.facebook.com/se vdamizafsin/posts/2530974180 448240/ E. T. 10.03.2020)

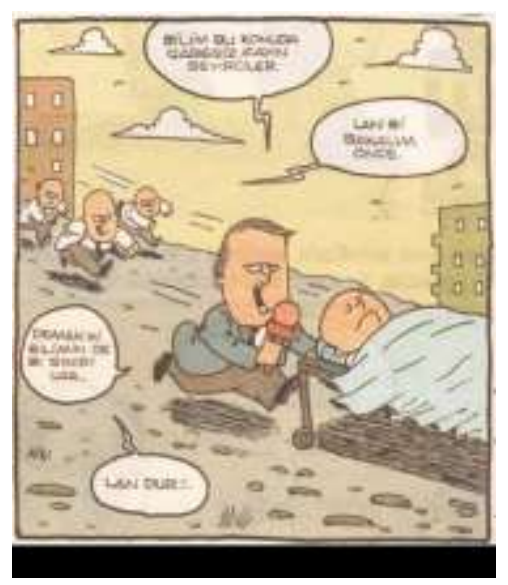

Görsel 5

(https://twitter.com/karika_TU RKolik/status/12388926969886 80198/photo/1 E. T. 14.03. 2020)

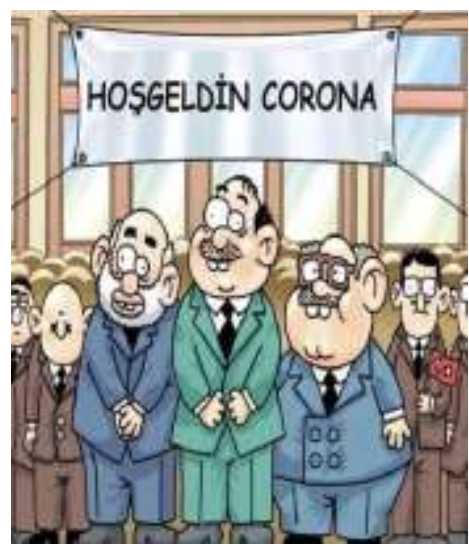

Görsel 6

(https://twitter.com/karika_T URKolik/status/1238071188 116701184/photo/1 E. T. 12.03.2020)

Korona virüsüyle ilgili üretilen mizah içerikleri hayatın her alanıyla ilişkilendirilmiştir. Görsel 7 ve 8'de kahvehane örneği kullanılmıştır. Virüsün Türkiye'de yayılmaya başlamasıyla birlikte kahvehaneler kapatılmış ve bu durum gündem konusu olmuştur. Medyada kaçak kahvehane haberleri, kahvehanelerde hijyen ve sosyal mesafe konularında pek çok haber yapılmıştır. Görsel 7'deki maske takarak okey oynayan insanların fotoğrafi, sosyal ağlarda çeşitli başlıklarla paylaşılmış ve yorumlanmıştır. Görsel 8'deki karikatürde kahvehanenin gündelik hayattaki yerine atıfta bulunulmuştur. Zamanının çoğunu kahvehanede geçiren insanlara gönderme yapılarak konu virüsle ilişkilendirilmiştir. İletişim teknolojilerinin gelişmesiyle ortaya çıkan yeni medya olgusu, insanların haber alma, haberi paylaşma ve tepki verme biçimlerini değiştirmiştir. Sosyal ağlar üzerinden dünyanın pek çok yerindeki olaylarla ilgili anlık haber alınarak kullanıcılar tarafından paylaşılır. 2020 yılına girişle birlikte dünyada ve Türkiye'de ortaya çıkan siyasi, ekonomik, askerî ve doğa olayları insanların zihninde gündemin üst üste birikmesine sebep olmuştur. Korona virüsünün yaygınlaşmaya başlamasıyla birlikte biriken bu gündeme mizah yoluyla tepki verilmiştir. Görsel 9' da korona virüsü, tarım arazilerine zarar veren çekirge sürüsü ve dünyaya yaklaşan astroid fotoğrafiyla ilişkilendirilmiştir. 


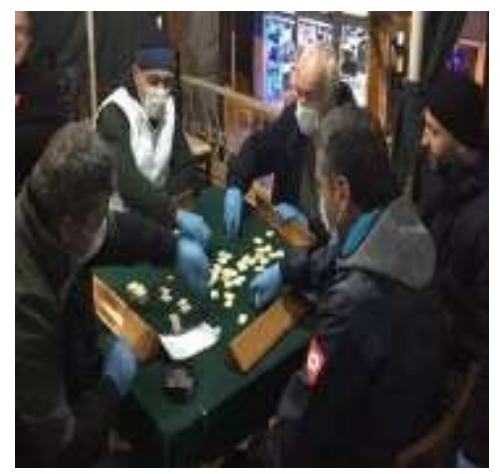

Görsel 7

(https://twitter.com/vaziyetco $\mathrm{mtr} / \mathrm{status} / 123835501184487$

0145/photo/1, E. T. 13.03.2020)

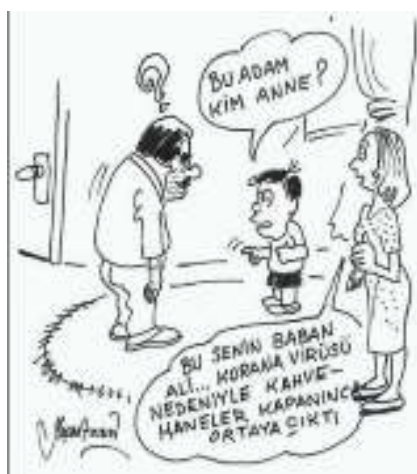

Görsel 8

(Kişisel WhatsApp grubu paylaşımından alınmıştır.)
Koronaya yakalanmadan øu bir/iki ayi atiatup.

yaklasmakte olen cekirge sorosonden canimizi

kurtarabilirsek, bu astroid de donyamiza dogmezse. 2020 nin ilk yarisin atlatmig sayitiriz, sonrasini bilemiyorum... SONUMUZ HAYIR OLUR INSSALLAH

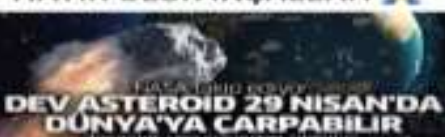

Dev asteroid 29 Nisarida Dunya'ya çarpabilir:

Görsel 9

(Kişisel WhatsApp grubu paylaşımından alınmıştır.)

Görsel 10, 2020'deki gündem sıkışmasına verilen bir diğer tepkidir. Korona virüsünün Çin'de ortaya çıktığı ve yaygınlaştığı haberleri, virüsle birlikte Çin'in de dünya gündemine oturmasına neden olmuştur. Yapılan paylaşımlarda, dünyadaki pek çok havaalanında Çinli olmayan çekik gözlü insanların, Çinli olmadıklarına dair üzerlerinde taşıdıkları yazılar mizah örneği olarak kullanılmıştır. Türkiye'de gündelik tüketim malzemelerinde Çin merkezli ürünlerin çokluğu ve bu ürünlerin bir kısmının kolay bozulabilir olması "Çin malı" deyimini yaygınlaştırmıştır. Buna gönderme yapılarak oluşturulan Görsel 11, sosyal ağlarda yoğun olarak paylaş1lmıştır. Mizah yoluyla ölümün bile Çin yüzünden çok ucuza gideceği belirtilmiştir.

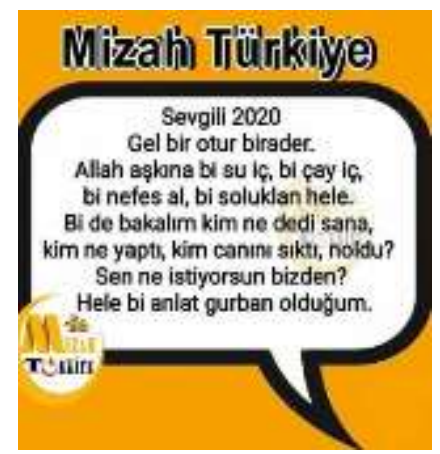

Görsel 10

(https://www.facebook.com/f.mizahturkiye/ph otos/a.735975059841680/2652926041479896/

?type $=3 \&$ theater E. T. 25.03.2020)

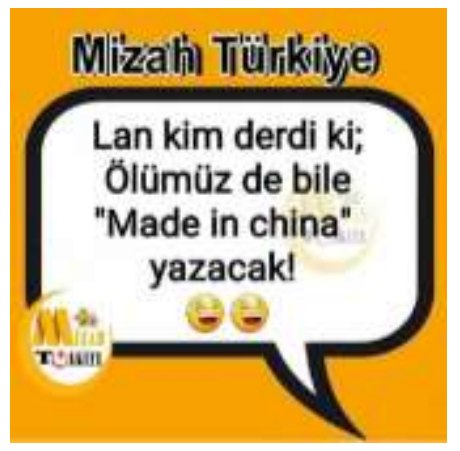

Görsel 11

(https://www.facebook.com/f.mizahturkiye/ph otos/a.735975059841680/2655128744592959/

?type=3\&theater E. T. 26.03.2020)

\section{Temizlik ve Kolonya}

Korona virüsü konulu sosyal ağlarda üretilen ve paylaşılan siber mizah içeriklerinin önemli bir bölümü temizlik konusunda olmuştur. Virüsün yayılmasını önlemek için yapılan uyarılarda dezenfektan kullanımı, sosyal mesafe kuralları, toplu taşımanın sınırlandırılması, maske kullanımı gibi konular ön plana çıkmışıı. Salgın sürecinde Sağlık Bakanlığının hazırladığı uyarı içerikleri, reklam kampanyaları ve diğer sivil toplum kuruluşlarının çalışmaları, temizlik konusunda 
farkındalığın oluşmasını amaçlamıştır. Sosyal ağ kullanıcıları, temizlik gündemini mizah içeriğine dönüştürmüştür. $\mathrm{Bu}$ içeriklerde kolonyanın çeşitli yönlerden ön plana çıktığı görülür. Kozmetik sektörünün geleneksel kültürü bugünkü kadar ürün çeşitliliğiyle etkilemediği dönemde kolonya, gündelik hayatta yaygın olarak temizlik ve koku ürünü olarak kullanılmaktaydı. Kolonyanın kültürel hafızadaki yeri, mizah unsuruna dönüşmesini kolaylaştırmıştır.

Görsel 12 ve 13'te, el yıkamayla ilgili örnekler verilmiştir. Abartı, mizahın önemli bir unsurudur. Görsel 12' de, gelecekte iş başvurusu yapan kişinin 2020 yılı boyunca sadece el yıkadığ karikatürize edilmiştir. Görsel 13'te, nesli tükenen bir hayvanın yok olmasının sebebi el yıkamamak olarak gösterilmiştir.

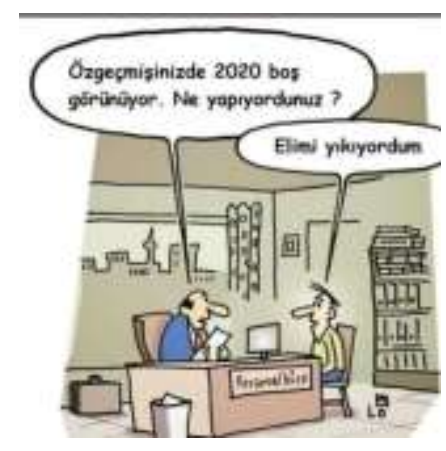

Görsel 12

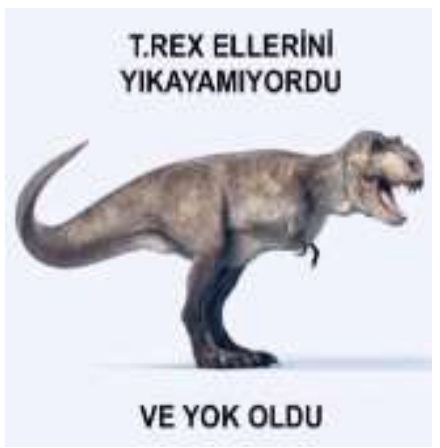

Görsel 13

(https://images.app.goo.gl/NmcNxW8K37bUYd (https://twitter.com/hicetikdegill/status/12394 D6A E. T. 09.06.2020)

Korona virüsü konusunda siber mizah üretirken kullanılan görsel malzemelerin bir kısmı, alakasız fotoğraflara eklenen ifadelerle oluşturulmuştur. Bu içeriklerde, bilinen televizyon dizilerindeki karakterler, replikler ya da mekânlar kullanılmıştır. Görsel 14 ve 15 'teki içerikler bunu örneklendirmektedir. TRT'de ve özel kanallarda yayımlanan Bizimkiler Dizisindeki Cemil karakterinin kullandığı "Sevim Koş" (Url 4) repliği, Görsel 14'te dizideki sahnenin fotoğrafi kullanılarak "Sevim koş, ülke mis gibi kolonya kokuyor." ifadesi eklenip salgınla ilişkilendirilmiştir. Bir diğer örnek, Aşk-1 Memnu Dizisinin 74. bölümünde, Bihter ve Behlül karakterlerinin telefon konuşmasından sonra Bihter' in "aptal her şey çok farklı olabilirdi aptal” (Url 5) cümlesi kullanılarak hazırlanmıştır. Bu ifade sosyal medyada pek çok konuyla ilişkilendirilerek paylaşılan popüler bir içeriktir. Görsel 15 'te aynı ifade kolonyayla ilişkilendirilmiştir.

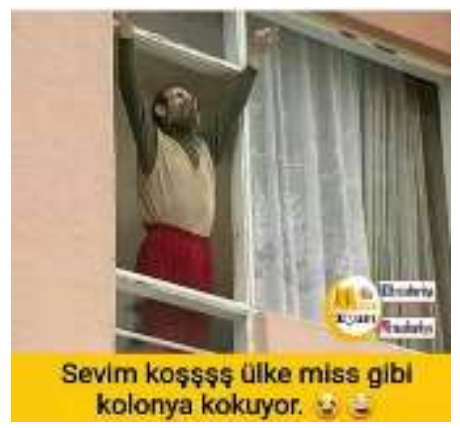

Görsel 14

(https://www.facebook.com/119814159411047/ photos/a.120029816056148/230458328346629/ ?type $=1 \&$ theater 17.03 .2020 )

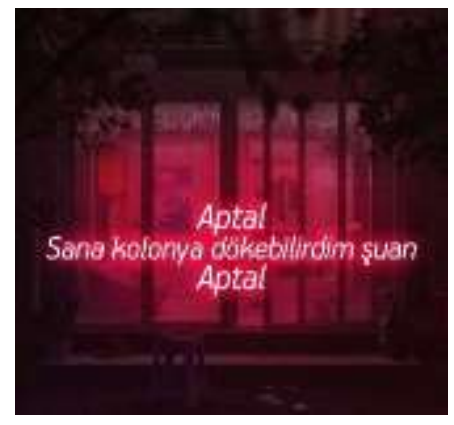

Görsel 15

(https://www.facebook.com/artoflostt/photos/ pcb.3342764859085630/3342764175752365/

?type $=3 \&$ theater 16.03 .2020 ) 
Korona virüsünü konu alan görsel mizah içeriklerinde kolonyanın ön plana çıkmasının sebebi, kolonyanın temizlik ve koku ürünü olmasıdır. Kolonyanın korona virüsünü öldürdügü yönündeki haberler üzerine yalnızca Google'da "kolonya virüsü öldürür mü?" sorusu üzerine 240,000 sonuç görülmektedir (E. T. 07.04.2020). Görsel 16'da, Attila İlhan'ın "Ben Sana Mecburum" şiirine nazire yapılarak kolonyaya övgü yazılmıştır. Görsel 17'de, Türkiye'de bilinen kolonya markalarının mart ayında doğan çocuklara ad olarak verilmesi önerilmiştir.

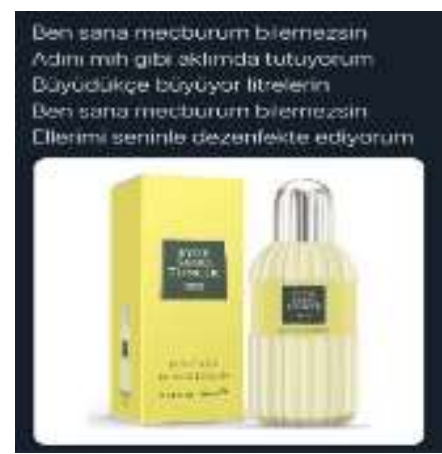

Görsel 16

(Kişisel WhatsApp grubu paylaşımından alınmıştır.)

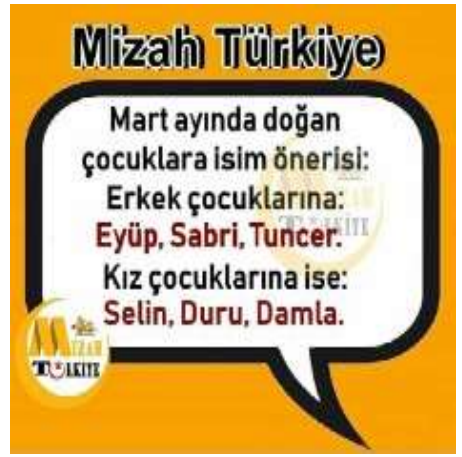

Görsel 17

(https://www.facebook.com/f.mizahturkiye/ photos/a.132237826882076/264177562259

4938/?type=3\&theater 19.03 .2020 )

Mizahta uyumsuzluk unsuru, sanal ortamda görsel mizah üretilirken yaygın olarak kullanılır. Görsel $18^{\prime}$ de, cepte taşınamayacak kadar büyük bir kolonya şişesini pantolonunun arka cebinde taşıyan bir kişinin fotoğrafi kullanılmıştır. Görsel 19'da kolonyanın gündelik hayat içerisindeki yerine gönderme yapılarak eve gelen misafire kolonya ikram edilmesi âdeti ile virüs korkutulmaya çalışılmıştır. Görsel 20'de Mevlana' ya gönderme yapılarak Mevlana görselinin üzerine "şu sıralar gelme" ve kolonya şişesi fotoğrafı eklenmiştir. Sosyal mesafe kuralları, oluşturulan içerikte mizah diliyle anlatılmıştır.

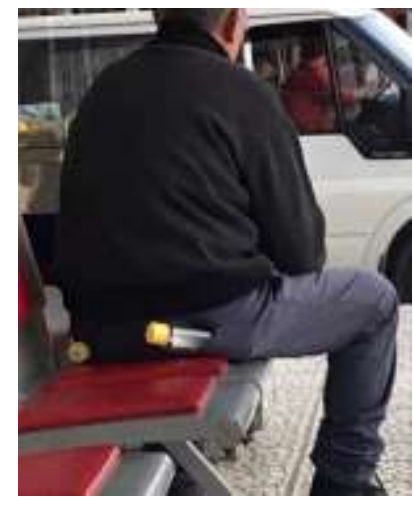

Görsel 18

(https://images.app.goo.gl/ 4ccRN4BeawoWvBXi9 E. T. 09.06.2020)

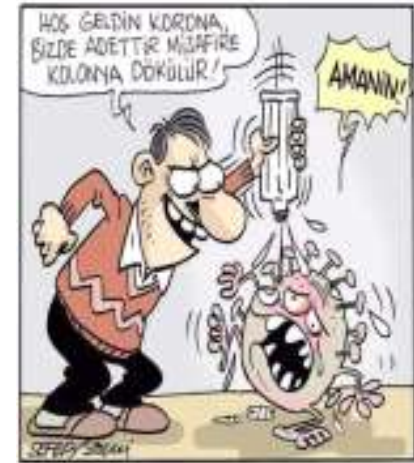

Görsel 19

(https://images.app.goo.gl/G yV6ZL4MBrNx6kVA9 E.

T. 09.06.2020)

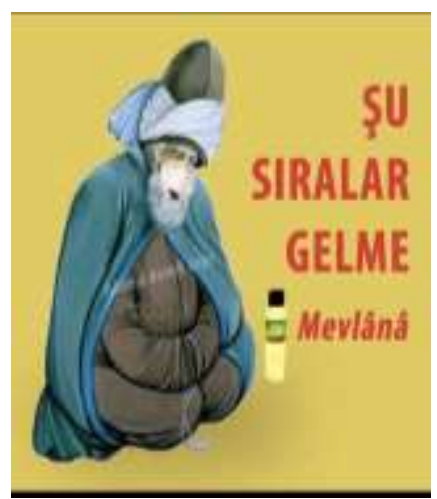

Görsel 20

(https://www.facebook.com/edaa ygentattoo/potos/a.5780907 $65883995 / 1120414294984970 / ? \mathrm{t}$ ype $=3 \&$ theater 19.03 .2020 ) 
Görsel 21'de sosyal mesafe kurallarına dikkat çekilerek bir film sahnesinden alınan fotoğrafla öksüren kişiler karşısındaki tavır gösterilmiştir. Virüsten korunmak için uygulanan sosyal mesafe kurallarında özellikle fiziksel temasa dikkat çekilmiştir. Görsel 21 ve 22'de Diriliş Ertuğrul Dizisindeki selamlaşma biçimine gönderme yapılarak fiziksel temastan kaçınmak gerektiği vurgulanmıştır.

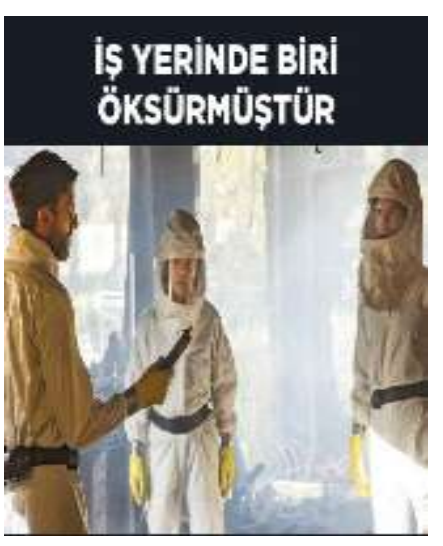

Görsel 21

(https://images.app.goo.gl/ MHCFcUzE2ztyg5ky5 E. T. 09.06.2020)

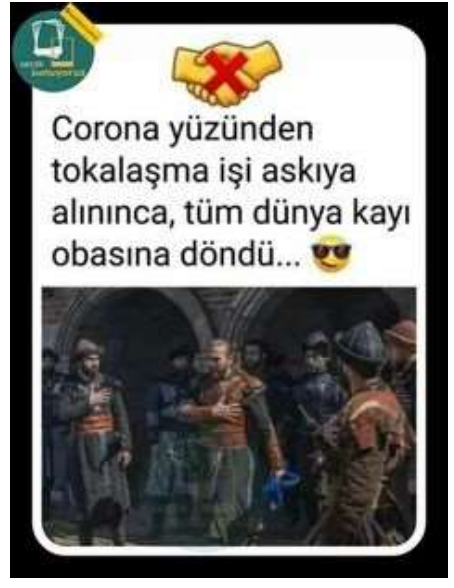

Görsel 22

(https://images.app.goo.gl/ V6DQRTxP5kVbKoGz6 E. T. 09.06.2020)

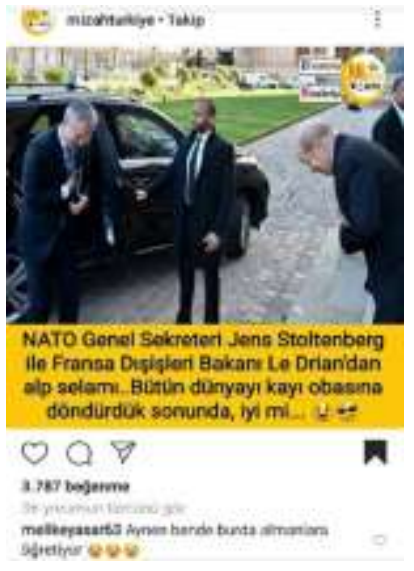

Görsel 23

(https://twitter.com/asoszen/status/1 238494890440474625/photo/1

13.03.2020)

Salgın sürecinde öne çıkan bir diğer konu maske kullanımıdır. Toplu bulunulan yerlerde maske kullanma zorunluluğu, maske takma konusunda önemli farkındalığın oluşmasını sağlamıştır. Evde yapılan çeşitli maske örneği fotoğraflarına eklenen ifadelerle bu konuda görsel mizah içerikleri oluşturulmuştur. Görsel 24'te örgüyle yapılan maske örneği kullanılmıştır. Sosyal medyada corona virüsüyle ilgili çeşitli kurum ve kuruluşların sayfalarından da pek çok paylaşım yapılmıştır. Görsel 25 'te Balıkesir Dursunbey Belediyesinin Twitter sayfasından yapılan paylaşım, ekran fotoğrafı alınarak kullanılmıştır. Sinek ilacı sıkma aracı olarak bilinen ve şiddetli beyaz duman çıkartarak ilaçlama yapan araç, virüse karşı tehdit unsuru şeklinde gösterilmiştir. 


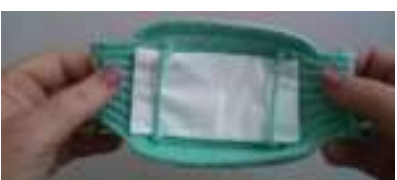

Zeki, çevik yurdum insani - seni sevmeyen ölsün. :-

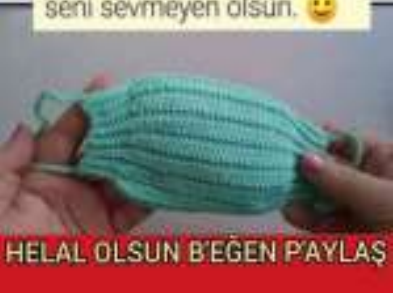

Görsel 24

(https://www.facebook.com/1466215583687062/ photos/a.1485599315082022/22

$41887802786499 /$ ?type $=3 \&$ theater E. T. 15.03.2020)

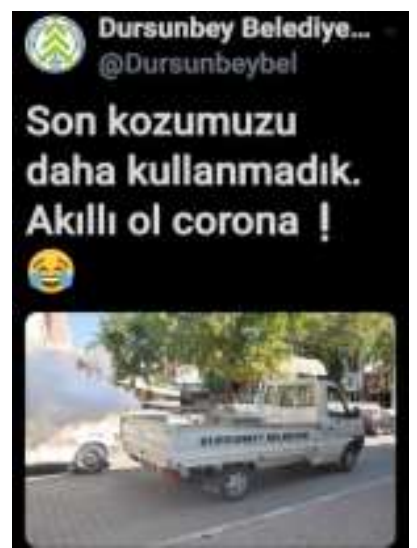

Görsel 25

(https://twitter.com/Dursunbeybel/status/123 8451898992254978/photo/1 E. T. 13.03.2020)

\section{Eğitim-Öğretim}

Corona Virüsünün yayılmasını önlemek amaçlı alınan tedbirler en geniş etkisini eğitimöğretim süreçlerinde göstermiştir. Okullar tatil edilmiş ve Milli Eğitim Bakanlığı TRT EBA üzerinden derslere devam etmiştir. Benzer durum üniversiteler için de geçerlidir. Üniversitelerde yurtlar boşaltılmış ve uzaktan eğitime geçilmiştir. Özellikle Twitter ve Instagram kullanıcılarının gündeminde olan bu durum, mizah içeriği üretiminde malzeme olarak kullanılmıştır. Dolaşıma giren görsel içerikler, çoğunlukla öğrencilerin evde olması ve uzaktan eğitimde kullanılan çevrim içi sistemlerle ilgili olmuştur.

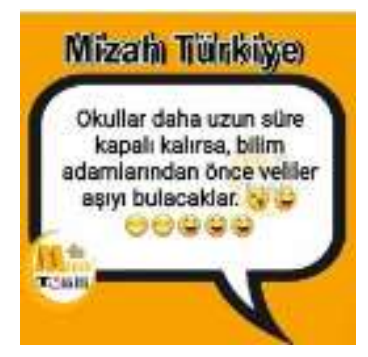

Görsel 26

(https://images.app.goo.gl/ srksbPMFSxNBZQLv6 E. T. 09.06.2020)

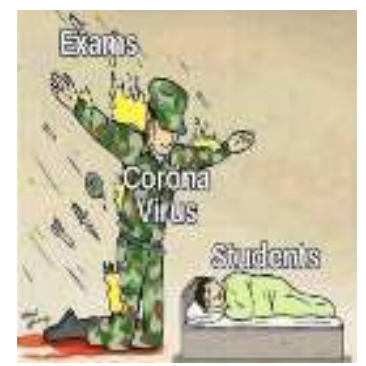

Görsel 27

(https://images.app.goo.gl/ Z6bZgNw4xYsxBDMJ7

E. T. 09.06.2020)

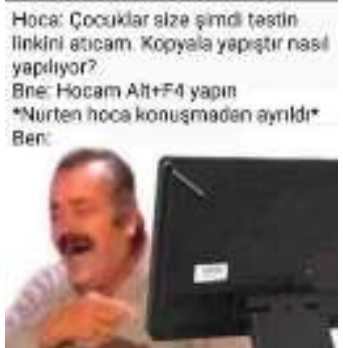

Görsel 28

(Kişisel WhatsApp grubu paylaşımından alınmıştır.) 


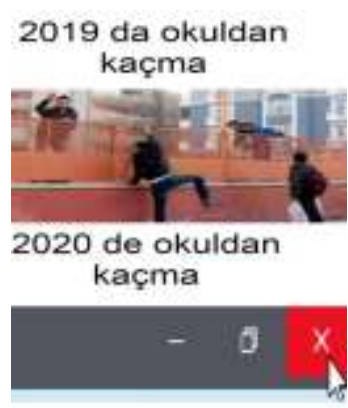

Görsel 29

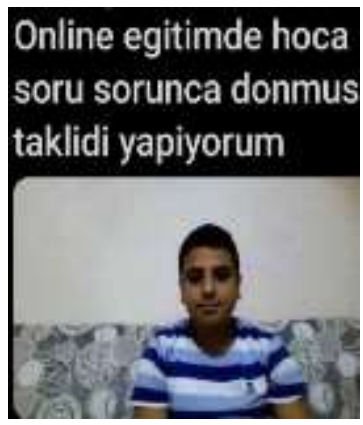

Görsel 30

(https://images.app.goo.gl/uGDv4XtMBDLN1g (https://images.app.goo.gl/ue3ZuThQyYNZ6c 1S8 E. T. 09.06.2020)

\section{Karantina ve Umreciler}

Korona virüsününün yayılmasını önlemek için alınan önemlerden birisi de karantina uygulamaları olmuştur. Önce yurt dışından gelenlerin on dört gün süreyle karantinada tutulmalarıyla başlayan süreç, daha sonra altmış beş yaş üzeri ve yirmi yaş altı kişilerin sokağa çıkma kısıtlamalarıyla devam etmiştir. Salgının yayılması üzerine büyük şehirlerde ve Zonguldak'ta nüfusun tamamına hafta sonları sokağa çıkma kısıtlamaları da getirilmiştir. Bu süreçte insanların evde vakit geçirmeleri daha çok sosyal medya kullanmalarını sağlamıştır. Evde kalma ve zorunlu karantina gündemi, görsel siber mizahın konularından birisi olmuştur.

Görsel 31'de uzun süre evde kalan kişinin kendini tanıyamaz hale gelişi, Kurtlar Vadisi Dizisinde Polat Alemdar karakterinin yüzünü değiştirdiği ameliyat sonrasındaki sahnenin fotoğrafi kullanılarak anlatılmıştır. Twitter'daki paylaşımlardan birisinde dizide geçen B.: "Bu yüz benim mi şef?" (Url 6) ifadesi de kullanılmıştır. Görsel 32'deki örnekte barbie bebek fotoğrafi kullanılarak karantinada evde kalınan süreçte kilo almaya gönderme yapılmıştır. Görsel 33 'teki diğer bir örnekte sürekli evde kalan kişinin psikolojisine gönderme yaparak kaktüsteki iğneleri sayacak kadar sıkılması konu alınmıştır.

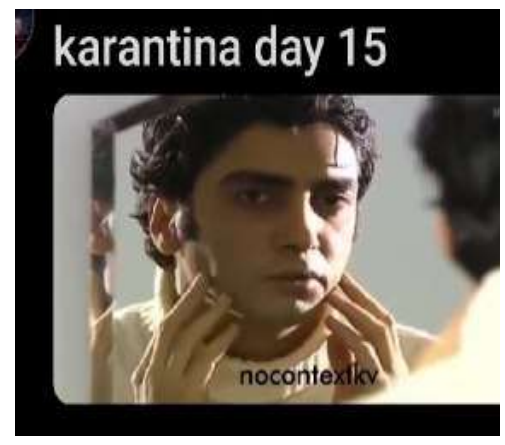

Görsel 31

(Kişisel WhatsApp grubu paylaşımından alınmıştır.)

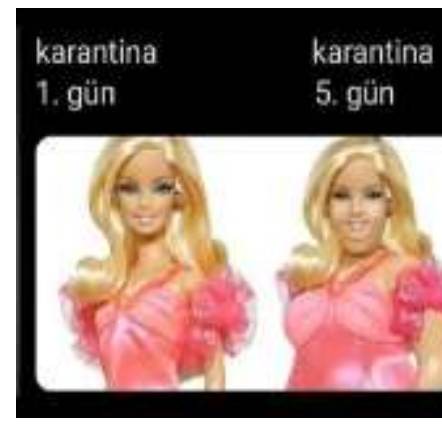

Görsel 32

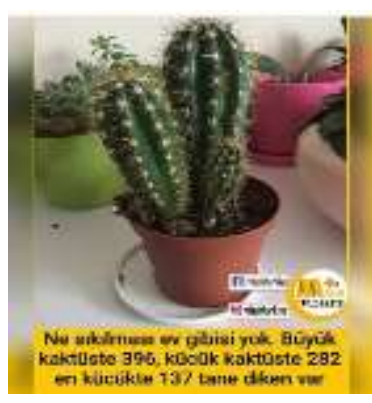

Görsel 33

(https://images.app.goo.gl /r 1heFWHTwp 62uiKDA E. T. 09.06.2020) (https://www.facebook.com/pg/ f.mizahturkiye/photos/?ref=page_i nternal E. T. 09.06.2020)

Karantina sürecinde gündelik hayat akışının değişmesile, insanların evde kalarak aile ortamında daha fazla vakit geçirmesi, sosyal farkındalık konularından birisi olmuştur. Üretilen ve 
paylaşılan mizah içeriklerinde iş, eğitim, kentleşme ve teknolojinin sonuçlarından birisi olarak sosyal bağların zayıflamasına atıfta bulunulmuştur. Görsel 34 ve 35 'te bir arada olan ailenin birbirinin fizikî-sosyal özelliklerini fark etmesi karikatürize edilmiştir.

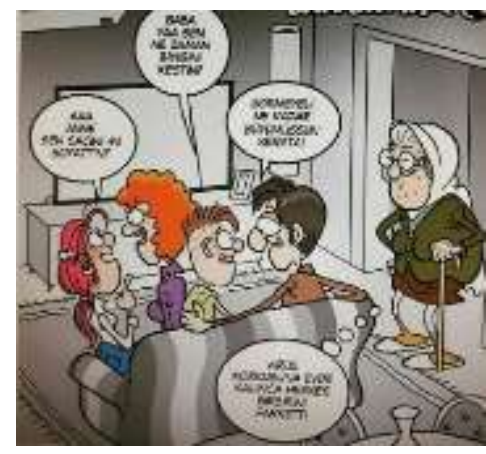

Görsel 34

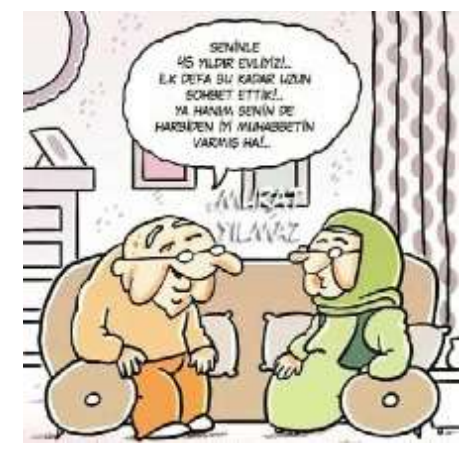

Görsel 35
(https://images.app.goo.gl/B2yFr8VWZCCPa pxb9 E. T. 06.09.2020)
(https://images.app.goo.gl/m5aTL8YU1wCHh 6eS8 E. T. 06.09.2020)

Paylaşılan görsel mizah içeriklerinin konularından birisi de umreden dönenlerin karantinaya alınmalarıyla ilgili tartışmalar olmuştur. Konunun gündem olmasının sebebi, virüsün yayılmasını önlemek amacıyla yurt dışından gelenlere uygulanan genel gözetim uygulamasıdır. Umreden gelenlerin bir bölümünün boşaltılan öğrenci yurtlarında on dört gün süreyle karantinaya alınması, öğrencilerin yurt hayatını gündeme taşımıştır. Umreden dönenlerin bir kısmı bu şekilde karantinada olmaya karşı çıkmıştır. Bu durumu konu alan Görsel 36'da umreden gelen ve evden çıkmaması için uyarıda bulunulan bir kişinin evde mevlit okutarak sosyal mesafe kuralını bozması konu alınmıştır. Görsel 37'de bir son dakika haberiymiş gibi düzenlenen, umreden gelen komşusunun kapisını kilitleyerek evden çıkmasına engel olan kişi haberi kullanılmıştır. İnternet sitelerinde böyle bir olayın gerçekten yaşandığıyla ilgili pek çok haber yer almıştır (Url 7). Görsel 38'de 65 yaş üzeri kişilerin sokağa çıkma yasağına uymaması konu alınmıştır. Bu kişilerin yasağa uymaması, ihtiyaçlarının karşılanması veya rencide edici şekilde sosyal medyaya yansıyan görüntülerin olması konuyu gündeme taşımıştır.

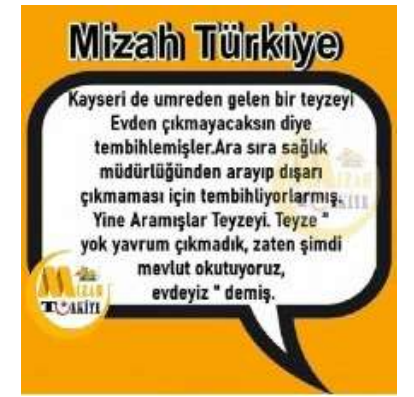

Görsel 36

(https://www.facebook.com/f. mizahturkiye/E. T. 09.06.2020)

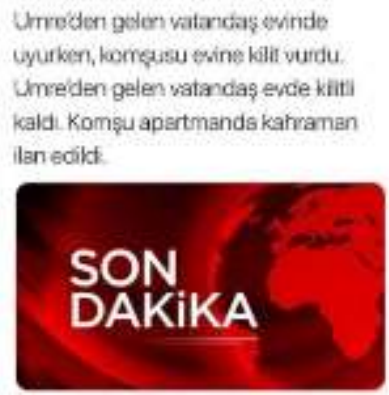

Görsel 37

(https://images.app.goo.gl/ ccyh1dHvrGjJQvWEA, E. T. 09.06.2020)

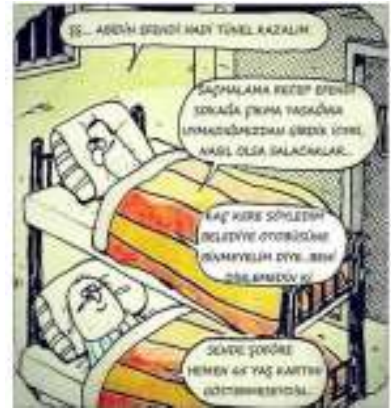

Görsel 38

(Kişisel WhatsApp grubu paylaşımından alınmıştır) 
Sosyal medyadaki siber mizah içeriklerinde görseller hazırlanırken herhangi bir fotoğraf konuyla ilişkilendirilerek kullanılabilmektedir. Araçtan çekilen, tabut taşıyan kamyon fotoğrafı pek çok paylaşımda kullanılmıştır. Görsel 39'da tabut taşıyan kamyonla, sokağa çıkma yasağına uymayanlara gönderme yapılarak virüsten dolayı ölüm oranlarının artacağına işaret edilmiştir. Görsel 40'ta virüsün ortaya çıkması ve yayılması Çin'le ilişkilendirilerek Çin'de uygulanan karantinada hayvanların rahat etmesi temsil edilmiştir. Virüsün Çin'de yenilen yarasalardan bulaştığı ve Çin'deki beslenme kültüründe pek çok hayvan türünün yenilebilmesi eleştirilmiştir. Görsel 41'de Kuzey Kore lideri Kim Jong Un'un fotoğrafı kullanılarak ülkedeki genel uygulamalara gönderme yapılmış ve yargısız infaz imasında bulunulmuştur.

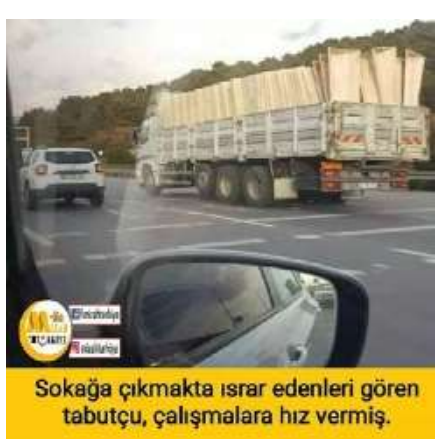

Görsel 39

(https://images.app.goo.gl/Peh DuB8DDdoVeu349 E. T. 09.06.2020)

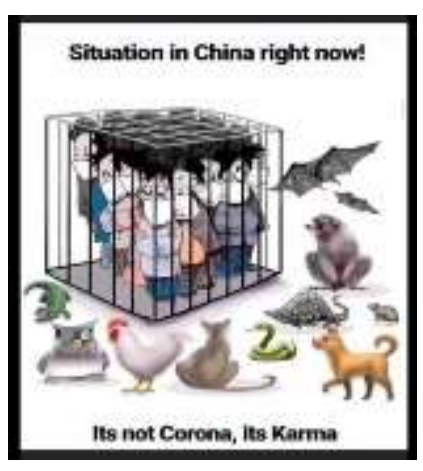

Görsel 40

(https://images.app.goo.gl/1nq NPSnv8pKwA4Uy7 E. T. 09.06.2020)

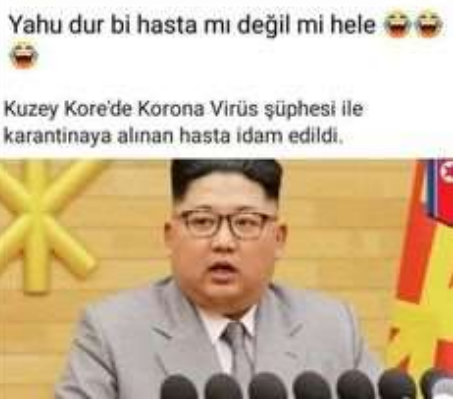

Görsel 41

(https://images.app.goo.gl/GE vpmriP46yjSHVK6 E. T.

09.06.2020)

\section{Stokçular}

Sosyal ağlarda dolaşımda olan görsel içeriklerde ön plana çıkan konulardan birisi de gıda ve temizlik ürünlerinin stoklanması olmuştur. Pek çok paylaşımda boş market rafları üzerinden özellikle makarna konusu mizah unsuru olmuştur. Görsel 42'de stokçular; makarnacılar, kolonyacılar ve tuvalet kâğıtçılar olarak gruplandırılmıştır. Sıkça paylaşılan içeriklerden birisi de berber ve güzellik salonlarının geçici olarak kapatılması konusunda olmuştur. Görsel 43'te ironi yapılarak artık herkesin gerçek yüzünün ortaya çıkacağı vurgulanmıştır. Görsel 44'te karantinanın bazı yerlerde hiçbir değişiklik yapmadığı Twitter'da paylaşılan Artvin fotoğrafi üzerinden vurgulanmıştır.

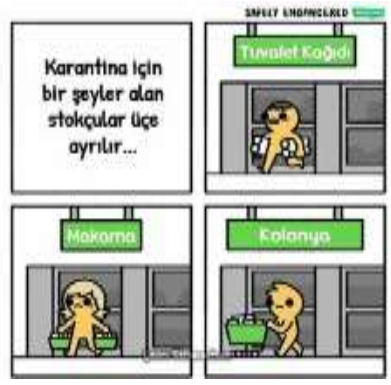

Görsel 42

(Kişisel WhatsApp grubu paylaşımından alınmıştır.)

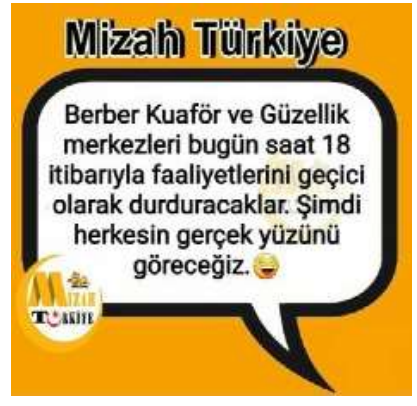

Görsel 43

(https://www.facebook.com/ pg/f.mizahturkiye/photos/?ref=page_ internal E. T. 09.06.2020)

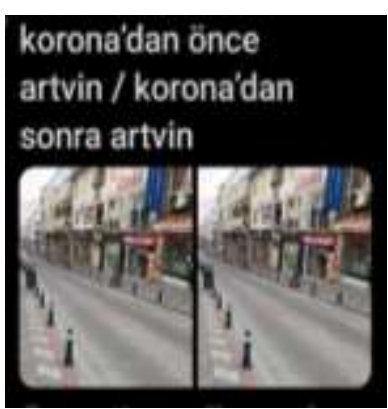

Görsel 44

(Kişisel WhatsApp grubu paylaşımından alınmıştır.) 


\section{Görsel-İşitsel İçerikler}

Korona virüsü gündemiyle oluşturulan siber mizah örneklerinin bir bölümü görsel-işitsel içeriklerledir. YouTube üzerinden dolaşıma giren videoların linkleri diğer sosyal medya ağlarından da paylaşılmıştır. Yazılı ve görsel mizah örneklerinde olduğu gibi, görsel-işitsel içeriklerin konusu da virüsün yarattığı etkiler, temizlik ve kolonya, eğitim-öğretim, karantina, yiyecek ve eşya stokları olmuştur. Buraya alınan iki örnek gıda tüketimi ve karantinayla ilgilidir. "Canan Hocamdan İnciler" başlıklı videoda Prof Dr. Canan Karatay taklidi yapılmıştır. Beslenme konusunda popüler bir isim olan Karatay, virüsle ilgili katıldığı televizyon programlarında salgına karşı bağışıklık sistemini güçlendirmek için kelle paça yeme önerisinde bulunmuştur (Url 8). Bu örnek üzerine Karatay sosyal medya da gündem olmuştur. Hazırlanan videonun deşifresi şu şekildedir:

Seyirci: Hocam korona virüsten korunmak için ne yapmallyı??

Canan Hoca: Bol bol işkembe, kelle, paça, mumbar, şırdan hatta ve hatta bol sarmısaklı sirkeyle ve limonla pişmiş koyun bacağı bulursanız doyasıya emcükleyebilirsiniz.

Seyirci: Hocam karantinadayken canım çok sıkıldl. Bir tencere helva kavurup yedim.

Canan Hoca: Koronadan sonra inşallah bizde senin helvanı kavurup yeriz. Şeker bağışıklı̆̆ düşürür çünkü. Elimde virüs olsa sana firlatırdım. Simdi, yaptı̆̆ın helvanın içinde margarin var mı?

Seyirci: Var.

Canan Hoca: Şeker var mi?

Seyirci: Var.

Canan Hoca: Ne duruyorsun? Kanser olsana. Şimdi de mekânın cennet olsun.

Seyirci: Hocam, peki hijyen için ne yapmalıyzz?

Canan Hoca: Hijyen için anti bakteriyel jeller, dezenfektanlar kullanmanız lazım. Kolonyanız her zaman yanınızda olsun. Bazen öyle gaza geliyorum ki kolonya ile zeytinyağı karıştırıp içesim geliyor. Fakat böyle bir şey yapmayın zehirlenip başıma bela olmayın...(Url 9).

Karantina sürecinde alınan tedbirlerden biri de 65 yaş üzeri kişilere sokağa çıkma kısıtlaması getirilmesi olmuştur. Bu konuda sosyal medyada mizah içerikli pek çok paylaşım yapılmıştır. YouTube'a yüklenen içerikler arasında aile ortamında çekilen videolar da vardır. Örnek olarak alınan videoda geçen diyaloglar şu şekildedir:

(Elleri ve ă̆zı bağlanarak sandalyeye oturtulmuş bir kişiye)

-Dışarlya niye gittin dün?

-Portakal getireyim dedim. Bırakın. Bir daha gitmem söz veriyorum.

-Söz mü baba? Aşağıya inmek yasak tamam mı?

-Tamam. Çayımı verin şimdi. (Sandalyeye bağlanmışs şekilde). Bir çay içeyim. Onur şu çayı ver oğlum (Url 10).

Korona virüsünü konu alan mizah üretimine televizyon dizileri de dâhil olmuştur. Star TV'de yayınlanan komedi dizisi Jet Sosyete'nin özel bölümü çekilmiştir. “Jet Sosyete Evdekal Özel Bölümü Deliliğe Çare Yok" adıyla dolaşıma giren çekimlerde, oyuncuların evlerinden çektikleri sahneler birleştirilmiştir (Url 11).

İletişim teknolojilerinin gelişmesiyle ortaya çıkan sosyal medya, kültürün sanallaşarak yeniden üretildiği ve tüketildiği bir ortam olmuştur. Zaman, mekân ve kimlik kavramlarının kırıldığı bu yeni ortamda "saat temelli nesnel şimdiki zamandan ziyade; internetin şimdiki zamanının 
yaşandığı" (Karadaş, 2015, 325-341) bir zaman algısı vardır. Bu sübjektif zaman içerisinde sosyal medyada kişiler sınırsız içerikle baş başadır. A ğ toplumunun üyeleri, bu içerikleri kullanarak etkileşime girmektedir. $\mathrm{Bu}$ kapsamda yeni "kimliklenme ve görünürlük biçimi" hayatı çevrimiçileştirmiş, çevrim içinin çevrim dışına etki ettiği bir "online toplum" yaratmıştır (Günden, Güzel, 2017: 169-188; Acar, 2008). Online toplumun var olma biçimidir gösteridir ve bu "gösteri birikimi" temsillerle sağlanır (Debord, 1996: 1). Modernizmle birlikte gerçeğin temsile bürünerek gösteri unsuruna dönüşmesi, teknolojik kültür ortamının doğuşuyla, gösterinin gösterisine dönüşmüştür. Sosyal medya bu dolaşımın iletişim ağı olarak gerçeğin yeniden yaratıldığı, paylaşıldığı ve tüketildiği bir ortamdır. Gündelik hayatın bütün unsurları bu çevrim içi süreçte veri olarak kullanılabilirken bir yandan da anlık bir etki-tepki ortamının varlığı söz konusudur. Sosyal ağların bir parçası olarak kişi, "pasif değil aktif” (Özdemir, 2009: 1277-1301) bir göstericidir. Bu paylaşım sürecinde aynı ağın üyeleri, tercihli birliktelikler kurup seçerek takipleştiği için farkındalığı yüksek bir iletişim ve etkileşim içerisindedir. Kovid-19 virüsünün etkileri mizah yoluyla bu tarz bir etkileşim biçimine dönüştürülmüştür. Siber ağ üyelerinin, "mizah ürettikleri durum, olay, kişi veya konular da günceldir" (Güzel, 2019: 219). Diğer yandan dijital ortamda üretilen mizah, geleneksel yapılardan da beslenir. Özdemir'in de ifadesiyle geleneğin bütün yapılarında olduğu gibi mizah da geçerli iletişim araç ve bağlamlarına göre yeniden oluşturulur (Özdemir, 2009: 1277-1301).

Sosyal ağlar üzerinden girilen etkileşim kültürel yapıları çeşitlendirir ve yeni ürünler ortaya çıkarır. "Kültürel yaratıcılık, türler, unsurlar, gelenekler ve yaratıcılar arası etkileşimlerin bir sonucudur. Etkileşimlerle yeni türler, gelenekler ve ürünler, hatta aktörler ortaya çıkar. Bu yaklaşıma, "yaratıcı kültürel etkileşim yaklaşımı" adı verilebilir." (Özdemir, 2010: 27-40). Bu bağlamda Korona virüsü gündemiyle ortaya çıkan mizahî içerikler bu etkileşimin sonucudur. Gündeme entegre olarak yaşayan ă̆ toplumu, yaratıcı siber mizah örneği olarak virüsün etkileriyle ilgili kendi tavrını geliştirmiş̧ir. Virüsünün bulaşıcılığı, onu konu alan mizahî içeriklerin üretim ve paylaşımının bulaşıcılığına dönüşmüştür. Bu bağlamda Bergson, "Gülme" adlı çalışmasında gülüncün yayılma kuvvetini açıklarken şu örneği verir:

\footnotetext{
"Herkesin gözyaşları döktüğü bir vaazda kendisine niçin ağlamadığı sorulan bir adam şöyle yanıt vermiștir: "Ben bu cemaatten değilim." Adamın ağlamakla ilgili söylediği gülme için daha da doğrudur. Ne kadar içten olduğunu zannetsek de gülme, gerçek veya hayalî, gülen diğer kişilerle yapılmış bir ittifakın, hatta neredeyse bir suç ortaklığının art düşüncesini barındırır. Tiyatroda, salon ne kadar doluysa seyircinin gülüşünün de o denli taşkın olacağı defalarca söylenmiştir.” (Bergson, 2014: 7)
}

Mizah kültürünün önemli bir parçası olan görsel içerikler, "yaratıldıkları dönemin sosyal, siyasal, kültürel, dinsel, ekonomik yapısını; abartı, alay, yalan, ironi, tezat" kullanılarak yansitırlar. Bu unsurlar genel anlamda mizahın bütün biçimleri için geçerlidir (Güvenç, 2019: 89; Feinberg, 2004: 105.113).

\section{Sonuç}

Makalede ağ toplumunun iletişim ve etkişelim biçimi, kovid-19 virüsü konu alan siber mizah örnekleri üzerinden ele alınmıştır. Ağ toplumunun oluşumu, teknolojinin bireyleri ve toplumları birbirine bağlayan sanal kültürel ortamları yaratmasıyla başlamıştır. Bilgisayarın askerî ve ticarî faaliyetlerle başlayan serüveni, taşınabilir mobil cihazlar ve internetle önemli kültürel sonuçları ortaya çıkarmıştır. İnternet, bireyleri ve toplumları birbirine bağlayarak uluslararası bir ağ şeklinde kültürün küreselleşmesini sağlayan önemli bir araçtır. İletişim teknolojilerinin gelişmesi ve taşınabilir mobil cihazların yaygınlaşması, internet ortamındaki sanal ağlar üzerinden yeni toplumsal etkileşim biçimini ortaya çıkarmıştır. Bu etkileşim biçimi, kişiyi aynı zamanda yeni kültür çevrelerine dâhil ederek sosyo-kültürel, politik ve ekonomik alanını genişletir. Sanal ağlar üzerinden etkileşim; yerel, ulusal ve uluslararası boyutta interaktif bir ağ toplumunu ortaya çıkarmıştır. Eğlence, eleştiri, haber alma gibi çeşitli konularda geniş olanaklar sağlayan internet ortamı kişiye aynı zamanda özgürlük duygusu verir. Gerçek kimlik kullanarak veya sahte kimliklerle sosyal ağlarda bulunma imkânı, bu ağların kullanım oranlarını arttırır. Gerçek kimlikle sosyal hayatta var 
olan kişi, aynı zamanda bir kamusal alan içerisindedir. Bu alanda belirli görev, sorumluluk ve sınırlılıklarla var olunur. Ancak internet ortamının çoklu kimlikle var oluş biçimi, bu unsurları içermez. A $\breve{g}$ toplumunun bu yeni üyelik biçimi esnek ve genellikle sorumluluktan uzak kimlikleri doğurur.

A $\breve{g}$ toplumun üyeleri, fiziksel gerçeklikte ve sözlü kültür ortamındakine benzer biçimde güncel bir etkileşim ve paylaşım içerisindedir. Yeni medya ortamında kendi medyasını kuran insan, güncel olaylarla ilgili bireysel tavrını anlık tepki olarak gösterebilmektedir. Çalışmada korona virüsü salgını sürecinde Facebook, Twitter, Instagram ve YouTube taramalarında konuyla ilgili yazıl1, işitsel, görsel ve görsel-işitsel siber mizah örnekleri toplanmıştır. Korona virüsünün önce yabanc1 ülkelerde daha sonra Türkiye'de gündem konusu olması, sosyal ağlarda mizahî tavırla karşılanmıştır. Gündelik hayatı bütün yanlarıyla etkileyen virüs salgınına ă̆ toplumunun tepkisi, siber mizah yaratmak şeklinde olmuştur. Sanal ortamın güncele endeksli kültürel üretim-tüketim tarzı, mizah boyutuyla ortaya çıkmıştır.

Çalışmada korona virüsü gündemiyle üretilen mizah içeriklerinde görsel mizah unsurlarının ön planda olduğu tespit edilmiştir. Görsel içeriklerde karikatür, fotoğraf ve capsler kullanılmıştır. Bu içeriklerde güldürü unsuru belirgin olmakla birlikte, eleştirel tavır da görülmüştür. Bir mizah içeriğinin üretiminden ziyade; paylaşım biçimi, paylaşım sıklığı, birden fazla sosyal ağda dolaşımda olması, sosyal ağ üyelerinin içeriğin yansıttığı düşünce ve duygu durumunu benimsediğini gösterir. Üretilen mizah içeriklerinin konuları, aynı zamanda virüsün toplumu hangi yönlerden etkilediğini göstermektedir. Çalışmada örnek olarak kullanılan yazılı, görsel, görsel-işitsel malzemeler olabildiğince belirli konu sıralaması içerisinde verilmiştir. Paylaşımlarda doğrudan corona virüsü, temizlik-kolonya, eğitim-öğretim süreçleri, karantina, yiyecek ve eşya stokçuları konularının ön plana çıktığı görülmektedir. Bu konular, virüsün gündelik hayata hangi açılardan yansıdığını gösterir. Mizah, bir yanıyla da gerçeğin bükülmesi ve başka bir dille ifade edilmesidir. Virüsle ilgili yapılan paylaşımlarda virüsten kaçmak yerine onunla mücadele mesajı verilir. Korona virüsünün Türkiye'ye gelmesiyle birlikte yasal önlemler alınmaya başlanmıştır. Virüsten korunmak için sosyal mesafe ve hijyen kurallarına dikkat çekme konusundaki uyarılar, mizah konusu olmuştur. Virüs salgınının yayılma ihtimaline karşı okullar tatil edilmiş ve uzaktan eğitime geçilmiştir. Bu uygulamaya üniversiteler de dâhil olmuştur. Bu durum, sosyal medya kullanıcılarının yaş aralığı dikkate alındığında, eğitim-öğretim süreçlerini gündeme taşımıştır. Evde aileyle vakit geçirme, sokağa çıkma yasağı, uzaktan eğitim uygulamaları yazılı ve görsel mizah içeriklerinde yer almıştır. Kısmi karantina süreçlerinde bir diğer gündem konusu da yiyecek ve temizlik malzemesi stoklamak olmuştur. Makarna, kolonya ve diğer temizlik ürünlerinin kullanımı üretilen mizah içeriklerine yansımıştır.

Sonuç olarak ağ toplumunun, sözlü kültür ortamındakine benzer şekilde anlık bir iletişim ve etkileşim içerisinde olduğu söylenilebilir. Salgın süreci, bu etkileşime mizah boyutuyla yansımıştır. Gülmenin bulaşıcılığı; kültürün yeni ortamlarında onu yaratan mizahın bulaşıcıllı̆ına dönüşür. Korona virüsü örneğinde, ulaşım ağı virüsün dünyada yayılmasına sebep olurken, iletişim ağı corona mizah virüsünün yayılmasını sağlamıştır. Fiber ağlarla birbirine bağlanan toplum, bu ağlarda siber mizah üretip paylaşarak etkileşime girmiştir.

\section{Kaynakça}

Acar B. (2008). Online Toplumun Doğuşu. http://www.uzunhikaye.org/icerik/online-toplumundogusu/ (E. T. 01.04.2020).

Aktaş, C., Berk Ç. (2013). Yeni Enformasyon ve İletişim Teknolojilerinin Sosyal Hayattaki Rolü. 1.Uluslararası Medya Çalışmaları Sempozyumu Bildiri Kitabı, (Editör Bilal Arık vd.), 629638. 
Arslan, A. S. (2017). Geleneğin Yeniden Üretimi ve Tüketimi Kapsamında Bir Deneme: Sosyal Medya ve Mizah. III: Uluslararası Halkbilimciler Sempozyumu Bildirileri, (Ed. Metin Özaslan) Hacettepe Üniversitesi Türk Halkbilimi Bölümü Yayınları: 2, 22-38.

Arslan, H., (2014). Toplumsal Olayların Ardından Sosyal Medya Başta Olmak Üzere Özellikle Dijital Ortamda Kendiliğinden Gelişen Mizahın İzahı, "Dijital İletişim Etkisi” Uluslararası Akademik Konferans Bildiri Kitab1, (Ed. Can Bilgili), İskenderiye Kitap, 267-277.

Avc1, A. (2003). “Toplumsal Eleştiri Söylemi Olarak Mizah ve Gülmece”. Birikim 166 (Şubat 2003) $80-96$.

Baudrillard, J. (2014). Simülakrlar ve Simülasyon (Çev. Oğuz Adanır), Doğu Batı Yaayınları.

Bergson, H. (2014), Gülme. Türkiye İş Bankası Kültür Yayınları.

Binark, M. (2015). Yeni Medya Çalışmaları Özel Sayısı Hakkında: Neden?, folklor/edebiyat, Yeni Medya Çalışmaları Özel Sayısı, C. 21, S. 83, 2015/3, 9-18.

Castells, M. (2008). Enformasyon Çağı: Ekonomi Toplum ve Kültür, Cilt 1 A ̆g Toplumunun Yükselişi (Çeviren: Ebru Kılıç.) Bilgi Üniversitesi Yayınları.

Çetin, İ. (2019). Elektronik Ortamda Mizah ve Mizahi Bir Tip: Baattin. Türk Edebiyatında Mizah Sempozyumu 13-15 Mayıs 2016, TDK, 517-536.

Debord, G. (1996). Gösteri Toplumu ve Yorumlar. Ayrıntı.

Dede, Ö. Y. (2014). Yeni Medya Ortamlarında Akıllı Telefonlar Üzerine Düşünmek. XIX. Türkiye'de İnternet Konferans1 Bildiriler Kitabı, (Editörler: Akgül Mustafa vd.), İnternet Teknolojileri Derneği, 63-71.

Denizci, Ö. Mert. (2009). Bilişim Toplumu Bağlamında İnternet Olgusu ve Sosyopsikolojik Etkileri, Marmara İletişim Dergisi Sayı 15, Temmuz 2009, 48-63.

Eker, Ö. Gülin. (2009). İnsan Kültür Mizah, Grafiker Yayınları.

Feinberg, L. (2004). Mizahın Sırrı. (Çev. Ali Çelik), Millî Folklor, Yıl 16, Sayı 62, 105-113.

Gençalp, H. (2019) Görsel Kültür, Çoklu Okuryazarlık ve Çoklu Biçimlilik Bağlamında Sosyal Medya İletileri. Global Media Journal TR Edition, 10 (19), 52-75.

Göker, G., Doğan A. (2011). Ağ Toplumunda Örgütlenme: Facebook’ta Çevrimiçi Tekel Eylemi. Balıkesir Üniversitesi Sosyal Bilimler Enstitüsü Dergisi Jun 2011, 14(25), 176-203.

Gönden, M., Güzel, M. (2017) Türkiye'de Sosyal Medyanın M/İzahı: Sosyal Paylaşım Ağlarındaki Deneyimlerin Karikatürlere Yansıması. Millî Folklor, 29(116), 169-188.

Güvenç, A. Ö. (2016). Anlatıdan Görsele Elektronik Mizah Kültürü. Türk Edebiyatında Mizah Sempozyumu 13-15 Mayis 2016, TDK. 79-90.

Güzel. C. (2019). İnternet Halkının Mizahı Sanal Âlemin Karagözleri, Türk Edebiyatında Mizah Sempozyumu 13-15 Mayıs, TDK. 217-223.

Karadaş, N. (2015) Zaman Kavramına Kuramsal Yaklaşımlar ve İnternet'te Şimdiki Zaman Olgusu. folklor/edebiyat, Yeni Medya Çalışmaları Özel Sayısı, C. 21, S. 83, 2015/3, 325-341.

Kırık, A. M. (2013). Gelişen Web Teknolojileri ve Sosyal Medya Bağımlılı̆̆ı, Sosyal Medya Araştırmaları "Sosyalleşen Birey" (Editörler Doç. Dr. Ali Büyükaslan, Yrd. Doç. Dr. Ali Murat Kırık). Çizgi Kitabevi.

Kırık, A. M., Saltık, R. (2017). Sosyal Medyanın Dijital Mizahı: İnternet Meme/Caps, Atatürk İletişim Dergisi, 12, 99-118. 
Karaduman, N. (2017). Popüler Kültürün Oluşmasında ve Aktarılmasında Sosyal Medyanın Rolü Erciyes Üniversitesi Sosyal Bilimler Enstitüsü Dergisi XLIII, 2017/2, 7-27.

Karagülle, A. E., Çaycı, B. (2014). A ğ Toplumunda Sosyalleşme ve Yabancılaşma, The Turkish Online Journal of Design, Art and Communication - TOJDAC January 2014 Volume 4 Issue $1,1-9$.

Koestler, A. (1997). Mizah Yaratma Eylemi, (Çev. Sevinç Kabakçığlu, Özcan Kabakçıŏlu), İris Yayınları.

Morreall, J. (1997), Gülmeyi Ciddiye Almak, (Çev. Şenay Soyer), İris yayınları.

Morreall, J. (2003) Gülmede Yeni Bir Teori (Çev.: Metin Ekici). Halkbiliminde Kuramlar ve Yaklaşımlar I. Milli Folklor Yayınları, 407-436.

Özay, E. N. (2018). Sosyal Medyada Yaratıcı Bir Eylem Olarak Trollük Ve Fotoğraf. Ege Üniversitesi V. İletişim Öğrencileri Sempozyumu "İletişimde Değişim" / 29-30 Kasım 2018 Sempozyum E-kitabı: http://community.ege.edu.tr/comm5/kounsmacilar/.

Özdemir, İ. (2012). Sanal Kültür Yanılsama m1, Gerçek mi? folklor/edebiyat, 18(71)4, 13-34.

Özdemir, N. (2009), Sanal Mizah, ICANAS 38, 10-15 Eylül, 1277-1301.

Özdemir, N. (2010). Mizah, Eleştirel Düşünce Ve Bilgelik: Nasreddin Hoca. Millî Folklor, 22(87), 27-40.

Özdemir, N. (2019). Dördüncü Sanayi Devrimi ve Gelenek Kültürü. 9. Türk Halk Kültürü Kongresi, Genel Konular, Bildiri Kitapçığı, Kültür ve Türizm Bakanlığı Yayınları, 207-241.

Öztürk, E. Çalıcı Can. (2018). Modern Toplumda Kimlik, "Siber Dissosiyasyon” ve "Siber Alter": Teorik ve Klinik Bir Yaklaşım. (Editör Öztürk E.), Ruhsal Travma ve Dissosiyasyon. Ankara: Türkiye Klinikleri, 39-47.

Oskay, Ü. (2011). İletişimin ABC’Sİ. 6. Baskı, Der Yayıncılık.

Ong., W. J. (2013). Sözlü ve Yazılı Kültür, Metis.

Postman, N. (2006). Teknopoli, (Çev. Mustafa Emre Yılmaz), Paradigma Yayıncılık.

Prestonm, C. L. (2014). Şaka. Millî Folklor, 26(101), 307-311.

Sanders, B. (2001). Kahkahanın Zaferi Yıkıcı Tarih Olarak Gülme, Ayrıntı.

Saka, E. (2019). Türkiye'de İnternet. Yeni Medya Çalışmaları V Türkiye İnternet Tarihi (Der. Erkan Saka), Alternatif Bilişim.

Sartori, G. (2004). Görmenin İktidarı Homo Videns: Gören İnsan. (Çev. Gül Batuş, Bahar Ulukan) Karakum.

Türkçe Sözlük.(2011). Ankara. Türk Dil Kurumu Yayınları. 11. Baskı

Türkiye Elektronik Haberleşme Sektörü Üç Aylık Pazar Verileri 2019 3. Çeyrek, Bilgi Teknolojileri İletişim Kurumu, https://www.btk.gov.tr/uploads/pages/pazar-verileri/3-ceyrekraporu2019.pdf (E. T. 17.03.2020)

Türkmen, F. (2013). Seyyid Burhaneddin Çelebi Letâif-i Nasreddin Hoca Nasreddin Hoca Lâtifeleri (Burhaniye Tercümesi), Büyüyenay Yayınları.

Vural, A. B., Bat, M. (2010). Yeni Bir İletişim Ortamı Olarak Sosyal Medya: Ege Üniversitesi İletişim Fakültesine Yönelik Bir Araştırma. Journal of Yaşar University, 20(5), 3348-3382.

Yıldırım, D. (1999).Türk Edebiyatında Bektaşi Fıkraları, Akçağ. 
URL1:https://dijilopedi.com/2020-turkiye-internet-kullanimi-ve-sosyal-medya-istatistikleri/ 22.03.2020

URL 2: https://hsgm.saglik.gov.tr/tr/covid-19-yeni-koronavirus-hastaligi-nedir

URL3:2https://www.cnnturk.com/video/turkiye/corona-virusu-son-dakika-turkiyeye-geldicoronavirus-belirtileri

URL 4:https://www.youtube.com/watch?v=cwdG_Ml42lU (E.T. 07.24.2020)

URL 5: https://www.youtube.com/watch?v=uYvCiHk2-EA (E.T. 07.24.2020)

URL 6: https://www.youtube.com/results?search_query=polat+alemdar+y\%C3\%BCz\% $\mathrm{C} 3 \% \mathrm{BCn} \% \mathrm{C} 3 \% \mathrm{BC}+$ ameliyat+sonras\%C4\%B1+sarg\%C4\%B1 (E. T. 08.04.2020)

URL 7: https://www.karadenizgazete.com.tr/gundem/umreden-gelen-komsusunu-evinekilitledi/263234 (E. T. 08.04.2020)

URL 8: https://www.youtube.com/watch?v=GXWCbDlMZpM E. T. 08.04.2020

URL 9: https://www.youtube.com/watch?v=injk5uyuWpY E. T. 22.03.2020

URL 10: https://www.youtube.com/watch?v=8SoSKycWKIU (E. T. 22.03.2020)

URL 11: https://www.youtube.com/watch?v=EAi1lDUwUy0 